Policy Research Working Paper 4471

\title{
Distortions to Agricultural Incentives in Australia Since World War II
}

\author{
Kym Anderson \\ Peter Lloyd \\ Donald MacLaren
}

The World Bank

Development Research Group

Trade Team

January 2008 
Policy Research Working Paper 4471

\section{Abstract}

Australia's lackluster economic growth performance in the first four decades following World War II was in part due to an anti-trade, anti-primary sector bias in government assistance policies. This paper provides new annual estimates of the extent of those biases since 1946 and their gradual phase-out during the past two decades. In doing so it reveals that the timing of the sector assistance cuts was such as sometimes to improve but sometimes to worsen the distortions to incentives faced by farmers. The changes increased the variation of assistance rates within agriculture during the 1950s and 1960s, reducing the welfare contribution of those programs in that period. Although the assistance pattern within agriculture appears not to have been strongly biased against exporters, its reform has coincided with a substantial increase in the export orientation of many farm industries. The overall pattern for Australia is contrasted with that revealed by comparable new estimates for other high-income countries.

This paper-a product of the Trade Team, Development Research Group—is part of a larger effort in the department to understand distortions to agricultural incentives globally. Policy Research Working Papers are also posted on the Web at http://econ.worldbank.org. The author may be contacted at kym.anderson@adelaide.edu.au.

The Policy Research Working Paper Series disseminates the findings of work in progress to encourage the exchange of ideas about development issues. An objective of the series is to get the findings out quickly, even if the presentations are less than fully polished. The papers carry the names of the authors and should be cited accordingly. The findings, interpretations, and conclusions expressed in this paper are entirely those of the authors. They do not necessarily represent the views of the International Bank for Reconstruction and Development/World Bank and its affiliated organizations, or those of the Executive Directors of the World Bank or the governments they represent. 


\title{
Distortions to Agricultural Incentives in Australia Since World War II
}

\author{
Kym Anderson, Peter Lloyd and Donald MacLaren
}

\author{
World Bank and University of Adelaide \\ kanderson@worldbank.org \\ kym.anderson@adelaide.edu.au \\ and \\ University of Melbourne \\ pjlloyd@unimelb.edu.au \\ d.maclaren@unimelb.edu.au
}

Keywords: Distorted incentives, manufacturing protection, agricultural assistance, trade

policy reform

JEL codes: F13, F14, Q17, Q18

This is a product of a research project on Distortions to Agricultural Incentives, under the leadership of Kym Anderson of the World Bank's Development Research Group (www.worldbank.org/agdistortions). The authors are grateful for research assistance from Ceren Erdogan, Esteban Jara, Marianne Kurzweil and Ernesto Valenzuela, for helpful comments from referees and workshop participants, and for funding from World Bank Trust Funds provided by the governments of Ireland, Japan, the Netherlands (BNPP) and the United Kingdom (DfID). The views expressed are the authors' alone and not necessarily those of the World Bank and its Executive Directors, or the countries they represent, nor of the countries providing the trust funds for this research project. 


\section{Distortions to Agricultural Incentives in Australia Since World War II}

\section{Introduction}

During the first four decades after World War II, Australia’s GDP per capita grew slowly relative to that in other high-income countries apart from the United States and New Zealand. In the past 20 or so years, by contrast, the Australian economy has outperformed most other high-income countries, with its per capita income growing half as fast again as the OECD average (Figure 1). This marked difference between recent and earlier relative performance has been attributed to major economic policy reforms that have occurred since the 1970s and, in particular, to the belated opening of the Australian economy to the rest of the world. Having been more protectionist than all other OECD countries except New Zealand for most of the twentieth century (Anderson and Garnaut 1987), and having largely stood aside from the industrial trade policy reforms agreed to by other Contracting Parties to the General Agreement on Tariffs and Trade (GATT) in the first seven rounds of multilateral trade negotiations (1947 to 1979), Australia has since undergone a remarkable degree of domestic microeconomic reform and opening up of its current and capital accounts. This liberalization has reversed the downward trend in its trade share of GDP, although no more so than for the average of other high-income countries - including the United States, whose share has trebled in the past three decades (Figure 2). 
It has been argued (e.g., by Anderson and Findlay 1995 and Anderson 1998, 2001) that Australia's lackluster growth performance in the first four decades following World War II was in part due to anti-trade and anti-primary sector biases in the government's industry assistance policies. How extensive were those biases, and to what extent did the timing of the cuts in sector assistance in recent decades reduce them? Did the variation of tariff-compensating industry assistance rates within the agricultural sector rise (thereby probably reducing the welfare contribution of those programs during that period) before it eventually fell? What has happened to the export orientation of the various farm industries in the wake of the reform process? And how does the overall pattern of distortions that has evolved for Australia compare with that for other highincome countries?

The present paper provides answers to these empirical questions using a new set of estimates of distortions to agricultural incentives. By way of background, it begins with a brief synopsis of structural changes to the Australian economy since the 1940s. It then describes the build-up first of manufacturing protection and some agricultural subsidies and then, from the 1970s, the dismantling of those interventions. In doing so a six-decade time series of nominal rates of protection is provided for both agriculture and other sectors producing tradables, most notably manufacturing. The paper concludes by contrasting them with new comparable estimates for the past 50 years for other highincome countries, before drawing lessons for other countries. 


\section{Growth and structural changes since World War II}

The comparatively poor growth performance of the Australian economy for most of the twentieth century contrasts with that since the late 1980s when it out-performed many other advanced economies in terms of GDP per capita growth (World Bank 2006). This was a period of especially rapid total factor productivity (TFP) growth (Parham et al. 1999, Dowrick 2001), in contrast to Britain for example where much of its catch-up was due to growth in employment and hours worked per worker (Card and Freeman 2002). Australia's annual TFP growth rate accelerated a full percentage point during the 1990s (Parham 2004). Since that was not the experience of other OECD countries, Parham asserts that domestic factors must provide a major part of the explanation, one important factor being the greater openness of the Australian economy to trade and investment. ${ }^{1}$

\footnotetext{
${ }^{1}$ Other areas of domestic reform that occurred simultaneously and boosted the gains from trade reform include deregulations (especially in the labour market), de-monopolization and privatization of government enterprises (especially in communications, utilities and transport infrastructure), and better management of the macroeconomy. There is now evidence that the rate of growth of productivity in Australia has since slipped behind that in several OECD countries (Dolman, Parham and Zheng 2007), perhaps due to the slowdown in Australia's pace of reform in recent years (Productivity Commission 2007). A more recent econometric study by Diewert and Lawrence (2006) demonstrates that productivity growth has been the dominant contributor to the growth in real welfare in Australia since 1960, with the terms of trade playing only a very minor role (even though prices in international markets for primary products relative to manufactures have been on a slight downward trend over the past century - see Pfaffenzeller, Newbold and Rayner 2007).
} 
For this natural resource-rich, relatively lightly populated economy, a modification of standard trade theory of sector comparative advantage (a blend of the Heckscher-Ohlin-Samuelson and Ricardo-Viner models provided by Krueger (1977) and explored further by Deardorff (1984) and Leamer (1987)) has been used successfully to explain the evolving sector pattern of exports of Australia (Anderson and Garnaut 1987; Anderson 1995b). However, a country’s production and trade specialization also depends on policy choices and their changes over time. In Australia's case, its long history of industrial protectionism resulted in a smaller share of GDP traded than would be normal for an economy of its size (Figure 2). ${ }^{2}$ It also ensured a bigger manufacturing sector than would have emerged under free trade, which was possible in its full-employment setting only at the expense of other sectors. The sector share of GDP held by manufacturing in the early 1960s was close to the OECD average of around 30 percent, despite the fact that Australia has always had few people relative to its rich endowments of agricultural land and mineral resources and so has a weak comparative advantage in manufactures. Meanwhile, the share of agriculture in GDP, employment and exports was at least ten times the mining sector’s share in the first dozen or so years after World War II (Table 1). For this reason, our paper has an agricultural focus.

The removal of the ban on key mineral raw material exports in the early 1960s and the tariff reforms of the 1970s and 1980s gradually corrected Australia’s promanufacturing policy bias. Between 1960 and 2005, manufacturing’s share of GDP fell

\footnotetext{
${ }^{2}$ The smaller shares for the large economies of Japan and the United States are to be expected, but even for those economies the share of GDP traded was rising during the 1960s and 1970s when it was falling slightly in Australia.
} 
much more rapidly for Australia than for the average OECD country, to just 11 percent, while the mining sector's share initially trebled (Anderson 2001). Mining's share of Australian exports also more than trebled between the early 1960s and the early 1980s, helped by the dramatic rises in energy raw material prices in the second half of that period (Table 1). It was not only natural resource-based exportables that Australia’s antitrade policies had discouraged, however. Export industries within the manufacturing sector and services exports were also discouraged. Together those two sectors contributed only one-twelfth of Australia's exports in the early 1950s, and even by 1980 their combined contribution was barely above one-quarter. However, by 1990 their share had risen to one-third and by 2005 to 44 percent or 22 percent each, thus exceeding the share for agriculture for the first time (Table 1).

Even though those changes lowered agriculture’s relative contribution to exports, the share of exports in the gross value of farm production nonetheless increased considerably, from around 55 percent in the mid-1970s to 75 percent now (ABARE 2007). Moreover, that growth in farm exports came from an increasing range of farm products, as farmers diversified beyond traditional wheat, wool and sheepmeat enterprises to beef, cotton, sugar, dairy products, wine and canola (Figure 3).

\section{Methodology for measuring distortions}

It is relative prices and hence relative rates of government assistance that affect producers' incentives. In a two-sector model an import tax has the same effect on the export sector as an export tax (the Lerner (1936) Symmetry Theorem), and this carries 
over to a model that also includes a third sector producing only nontradables (Vousden 1990, pp. 46-47). It was this understanding that led Gruen (1968) to point out that raising assistance to agriculture in the presence of high assistance to manufacturing could increase rather than reduce national economic welfare. ${ }^{3}$ For that reason we report estimates not only of the average nominal rate of assistance (NRA) for the tradable parts of the agricultural sector, but also of the average NRA for the tradable parts of all nonagricultural sectors. The NRA is the percentage by which government policies have raised gross returns to producers above what they would be without the government's intervention. They are based on NRA estimates for individual industries. With those two sector NRAs we then calculate a Relative Rate of Assistance, RRA, defined as:

$$
\text { RRA }=100[(1+N R A a g t / 100) /(1+N R A n o n a g t / 100)-1]
$$

where NRAag $^{\mathrm{t}}$ and NRAnonag ${ }^{\mathrm{t}}$ are the average percentage NRAs for the tradables parts of the agricultural and non-agricultural sectors, respectively. Since the NRA cannot be less than -100 percent if producers are to earn anything, so too must the RRA. This measure is useful. If it is below zero, it provides an internationally comparable indication of the extent to which the policy regime has an anti-agricultural bias, and conversely when the RRA is positive.

The cost of government policy distortions to incentives in terms of resource misallocation are greater the greater the degree of substitution in production (Lloyd

\footnotetext{
${ }^{3}$ A policy debate followed Gruen’s famously unpublished 1968 paper, with some arguing for tariffcompensating farm assistance to continue until manufacturing tariffs were brought down e.g., Harris et al. 1974, Harris 1975) while others (e.g., Lloyd 1975a, Warr 1978) pointed out the political economy dilemmas and other problems this could raise.
} 
1974). In the case of agriculture which involves the use of farm land that is sectorspecific, the greater the variation of NRAs across industries within the sector, the higher will be the welfare cost of those market interventions. A simple index of that cost is the standard deviation of industry NRAs within agriculture. We therefore report not only the weighted mean NRA for the sector (using the values of production at unassisted prices as weights), but also the standard deviation around that mean each year. ${ }^{4}$

\section{Measuring the nominal rates of assistance (NRAs)}

We begin by describing the sources of agricultural NRAs, before turning to those for non-agricultural tradable sectors.

\section{Agricultural commodities}

Australia’s Industries Assistance Commission began calculating estimates of the nominal rates of assistance for major agricultural commodities beginning with the year 1970-71. (All years are fiscal, beginning 1 July.) This series has been continued by its successors,

\footnotetext{
${ }^{4}$ The effective rate of assistance (ERA) is, in principle, a better partial equilibrium measure of distortions to producer incentives than the nominal rate. This is because, in showing how value added rather than the gross value of production is affected, it takes into account differences in the value added share of output as well as distortions to intermediate input prices. Our simpler approach is dictated not only by insufficient Australian data prior to the 1970s but also by the comparable ERA estimates are not available for other countries. We do, however, attempt to capture input price distortions by estimating their equivalence in terms of a higher output price and including that in the NRA for agriculture.
} 
the Industry Commission and the Productivity Commission. ${ }^{5}$ There are four breaks in the series as each sub-series is benchmarked to the reference years 1970-71, 1983-84, 199091 and 1996-97. There are some differences between periods in the estimation methodologies used. For example, the first three series were compiled on an agricultural commodity basis, while for the latest (1996-97 benchmarked) series the Productivity Commission moved to a ANZSIC industry-based classification of activities, in line with the methodology used for the manufacturing sector industries (see Productivity Commission 2002c, Methodological Annex A). For this reason, the series for individual activities other than dairy, poultry and pig farming are not available from 1999-2000 from the Commission. As it happens, almost all the other farm industries had zero nominal assistance by then. We have assumed this continued to be the case, which is consistent with PSE estimates for Australia by the OECD (2006). Two exceptional farm products were rice and oranges, and their small 1999-2000 NRA values are assumed to continue to $2004-05$ (rice 1.7 percent and oranges 0.6 percent). ${ }^{6}$

For the years before 1970-71, the only comprehensive series available is that published in Lloyd (1973, pp. 149-58), which was prepared by Australia’s Bureau of Agricultural Economics. Those authors followed one of the methods used by Harris (1964) in his pioneering paper on agricultural protection in Australia, as explained in Lloyd (1973, Appendix Notes). They cover the major agricultural commodities for which

\footnotetext{
${ }^{5}$ On the history and workings of this remarkable transparency agency and the policy reform process of which it has been an active participant since it superseded the Tariff Board in 1973, see Productivity Commission (2003).

${ }^{6}$ For rice, this is very close to the calculations made by the OECD (2006).
} 
data were available at the time, for the years $1946-47$ to $1970-71 .^{7}$ The Lloyd/BAE series and the PC series use essentially the same methods. Commodities are designated as either export or import-competing and then direct estimates of the implicit price changes to producers resulting from agricultural assistance are made and expressed as a percentage of the export or (in the case of tobacco and cotton pre-1970) the import parity price.

The two series report estimates for one year in common, 1970-71. This common year provides a check on the comparability of the two series. It turns out that the estimates for that year are very close with the exceptions of tobacco and eggs. ${ }^{8}$ In blending the two series of estimates, the PC's are used from 1970-71 (see Table 2).

For the industries covered by the Commission but not by Lloyd, 'guesstimates' have been made for the years before 1970, based on the policy descriptions in Edwards (2006) and the references cited therein. The only guesstimate of significant size is for wine grapes, whose NRA is assumed to equal that estimated by Lloyd for dried vine fruit

\footnotetext{
${ }^{7}$ For milk prior to 1970-71, we took a simple average of the Lloyd/BAE estimates for Butter and Cheese to get the milk NRA shown below in Table 2 for those years. The Lloyd/BAE and the PC series for the main distorted commodities are reported by individual commodity and year in the Appendix to Anderson et al. (2007).

${ }^{8}$ For tobacco the differences are explained by differences in the source of imports used to establish the import parity price. Imports of tobacco leaf used in the manufacture of tobacco products in Australia varies greatly in quality and price by source. The choice of source to establish the import parity price is discussed at length in reports by the Industries Assistance Commission (1981, Appendix 5; 1983a, chapter 6.4; and 1983b, Section 4.2). For eggs, it is not clear why the Lloyd/BAE and the PC series give such widely different estimates of the level of assistance, as they cover the same forms of assistance and use similar methods. That industry has a very small weight in the sectoral aggregate, however, so it does not affect the average NRA for the sector as a whole.
} 
up to 1970. All the other industries had either no assistance (maize, oats, rapeseed, soybean, bananas, olives, wool, beef, sheepmeat, pigmeat, chicken meat) or a very small weight in the total gross value of farm production. For the latter category, NRAs are assumed to be: apples 6 percent, oranges 25 percent and potatoes 8 percent for the 1950s and 1960s, and zero for all three crops prior to 1950-51.

To obtain the weighted averages for agriculture as a whole, shown in Table 3, we first assumed the NRA was zero for products not covered by the above estimates and 'guesstimates'. This is reasonable since those not covered are mostly small horticultural industries which are not subject to market interventions (apart from quarantine restrictions, which are in place purportedly for reasons of health rather than economic protection reasons). As weights we used gross value of production at undistorted prices, calculated by dividing that value at domestic producer prices - or, equivalently, the NRAs - by (1+NRA/100).

The fourth row of Table 3 includes 'non-product-specific' assistance (including all assistance via factor and intermediate input markets, even though some of that is in fact product-specific), estimates of which are taken from the Productivity Commission for the period from 1970. We assume them to have been 1.8 percent of the gross value of farm production in 1969, 2 percent in 1960, 0.5 percent in 1946, and linear interpolations between those years. 


\section{Non-agricultural tradable commodities}

The Productivity Commission has not provided systematic NRA estimates for mining for every year, but for those years that it has done so in recent decades the values are extremely small, varying within the range of -1 to +1 percent. We therefore simply assume that the sector's NRA has been zero since 1960 when the ban on exports of iron ore and coal was lifted. We also assume it is zero for other primary products (forestry and fishing), as they are not subject to government interventions other than for resource and environmental conservation reasons (and in any case they represent a very small fraction of even just the tradables’ share of GDP).

Estimates of the NRA for manufacturing for the period prior to 1968-69, when Tariff Board estimates begin, rely on tariffs only. During 1952 to 1960 there were also protective quantitative restrictions on imports of manufactures (ostensibly for balance of payments reasons in the presence of fixed exchange rates - see Moffatt 1962, 1970), but since we do not have estimates of the protective effects of those import licenses, we simply assume their impact on the average NRA for non-agricultural tradables is exactly offset by the negative impact of the ban on key mining exports in those years. ${ }^{9}$

\footnotetext{
${ }^{9}$ In years prior to the 1950s, the relatively low international prices of mineral and energy products (World Bank 2000), combined with the very high cost of transporting bulky coal and iron ore from Australia to the North Atlantic's industrial hub, means that the export ban was probably redundant. In the 1950s the ban signalled Australia’s unwillingness to provide industrial raw materials to Japan - a foreign policy stance that was reversed after the signing of the Australia-Japan trade agreement in 1957 (Crawford 1968). For more on mining policies historically, see Doran (1984), and on mineral taxation in particular, see Groenewegen (1983).
} 
Since Australia’s imports pre-1970 were almost exclusively manufactures, customs revenue as a percentage of the value of all merchandise imports provides a reasonable proxy for the country's nominal rate of tariff protection for manufacturing. Annual estimates from 1945-46 of that indicator are reported in Appendix Table 1, along with estimates referring just to dutiable imports, using data from the Australian Bureau of Statistics (ABS, previously the Commonwealth Bureau of Census and Statistics, CBCS). The latter were compiled by Lloyd (2006, 2007).

These series relate to customs duties only and so do not include assistance due to non-tariff measures, apart from anti-dumping, countervailing and revenue (“Primage”) duties. They do include an adjustment for refunds and drawbacks of customs duties though, and they include primage duties where applicable, which is important because these added significant protection to Australian producers of many goods. The first column of Appendix Table 1 also includes duties levied on excisable goods, ${ }^{10}$ and refers to actual rates levied on imports, thereby combining MFN, preferential and concessional tariffs on final goods and intermediate or capital inputs. As those inputs that were not competitive with Australian-produced goods were admitted duty free under by-law and concessional import schemes, the series has long been regarded as less useful than the series of the average tariff on dutiable imports only. Thus the best available series measuring the average nominal protection due to the Australian tariff over the period to 1968-69 (after which more-comprehensive Productivity Commission estimates are

\footnotetext{
${ }^{10}$ Ideally the duty collected should be adjusted to cover only the margin over the excise duty levied on like Australian-produced goods, but that was not possible.
} 
available) is that in the second column of Appendix Table 1, where averages are calculated using import weights. ${ }^{11}$

For the period since 1968-69, the Productivity Commission (and its predecessors the Industries Assistance Commission and the Industry Commission) provides estimates of both nominal and effective rates of assistance to manufacturing, for industry subcategories down to the 4-digit level. In addition to tariffs these cover subsidies, bounties and discriminatory sales taxes. Initially they did not cover quantitative restrictions, content plans, etc. (Industries Assistance Commission 1976, p.4), but these are included from 1982-83.

The average nominal rate of assistance on outputs (NRAs) for the whole nonagricultural tradables sector is reproduced in the final column of Appendix Table 1. To get that average, we assumed only (and all) service sectors produce non-tradables, and a zero NRA for non-agricultural primary sectors. For manufacturing, we use the Productivity Commission NRA output estimates from 1968-69 (ignoring their estimates of net assistance via primary factor and intermediate input markets, which in the past decade would have lowered them by about one-fifth), while for earlier years the dutiable import tariff averages estimated by Lloyd are used (the second column in Appendix Table 1). The latter may overstate assistance to the sector in so far as some competing imports come in duty free; but that is assumed to be offset by the numerous non-tariff barriers to imports that were in place in the years prior to 1970. For the two years of overlap in the two series in the late 1960s, they are almost identical (at 23 percent). The

\footnotetext{
${ }^{11}$ For an extensive discussion of the strengths and weaknesses of these calculations, including their weighting systems, see the Appendix in Anderson et al. (2007).
} 
manufacturing sector's share of non-agricultural tradables output is assumed to be in proportion to its share of GDP from manufacturing plus non-agricultural primary activities, shown in column 4 of Appendix Table 1. That share times the manufacturing NRA in column 2 or (after 1967-68) column 3 provides the estimated NRA for total nonagricultural tradables, shown in the final column of Appendix Table 1.

\section{The NRA estimates and the evolution of policies}

In addition to reporting the NRA estimates, this section provides a brief history of policies up to the early 1970s and then of changes thereafter, particularly when the reforms accelerated in the mid-1980s. As there were relatively few agricultural subsidies or farm import barriers (other than quarantine restrictions) through most of the past six decades, the story is more about the indirect anti-agricultural bias that resulted from the protection of manufacturing. Nonetheless, coverage of policies that directly distorted various agricultural markets post-World War II also is included.

\section{Prior to the early 1970s}

The long history of industrial protectionism has its roots even before the formation in 1901 of the Australian Federation. Tariff revenue in the first decade of Federation accounted for one-fifth of government revenue. That is very high for what at the time was one of the world's highest-income economies, as that share typically falls as per capita income rises. It is twice that of the Nordic countries, for example, even though their per 
capita incomes were barely half Australia’s (Mitchell 2003a,c). Tariffs on manufactures rose steadily in the decades that followed, from a little less than 30 percent on average in the first quarter of the century to more than 50 percent in the next 20 years. They were supplemented by quantitative import restrictions first imposed in the late 1930s as ‘wartime measures', and by import licenses after World War II. They then rose even further in the 1960s when they substituted for the import licenses as the latter were mostly removed in 1960 (with minor exceptions). ${ }^{12}$

This trend over the 1950s and 1960s contrasted strongly with what other highincome countries were doing at that time, which was lowering tariffs on manufactures as part of multilateral trade negotiation under the General Agreement on Tariffs and Trade (GATT). ${ }^{13}$ Hence, by the early 1970s, Australia’s average manufacturing tariff exceeded that of most other OECD countries (Anderson and Garnaut 1987).

\footnotetext{
${ }^{12}$ The first major tariffs for the Australia federation were imposed in 1907. According to the indexes constructed by Carmody (1952), by the 1920s the decade average of the general tariff on Australia's imports of items other than food, beverages and tobacco was double that 1907 level, and by the 1930s it averaged 60 percent higher than in the 1920s. Vernon (1965) reports averages for tariffs above 12.5 percent for the period from 1938-39 to 1962-63: that average dipped somewhat in the late 1940s/early 1950s when import licences became the binding constraint, but by the early 1960s they were back to the level of the late 1930s.

${ }^{13}$ The GATT came into effect in 1948. Even though Australia was a founding signatory to that Agreement, it chose not to join the commitments to cut manufacturing tariffs - claiming (disingenuously) that it was still a developing country but also out of frustration with the unwillingness of other GATT contracting parties to commit to lowering their agricultural protection rates (Arndt 1965, Snape 1984, Anderson 1999, Capling 2001).
} 
Meanwhile, the government intervened in numerous markets for farm products, but the subsidies and protection they provided to agricultural industries were only a modest offset to the indirect disincentives caused by manufacturing protection during this era. In the immediate post-World War II period, Australia’s agricultural programs were directly taxing the farm sector. Most of that was removed by the end of the Korean War, at which time farmers were enjoying a boom in export prices that spurred the highest inflation in Australia since its gold-rush era of the 1850s. Farm assistance then rose gradually such that by the end of the 1960s the nominal rate of assistance averaged 17 percent. During that period the standard deviation of agricultural NRAs rose even more than the mean, indicating increasing misallocation of resources within the agricultural sector (Table 2).

A striking feature of agricultural assistance at that time was that it applied to export industries almost as much as to import-competing ones (Figure 4). Assisted export industries in Australia included wheat, manufactured dairy products, sugar and dried vine fruit. The schemes often also contained so-called home consumption price schemes whereby domestic consumers were forced to pay more than the export price (Sieper 1982, Edwards 2006). Those schemes, which required the pooling of domestic and export returns, ${ }^{14}$ could only be implemented with the support of Australia's state governments.

\footnotetext{
${ }^{14}$ That pooling was inefficient in at least two senses: it led to excessive volumes of production because producers received the average rather than the marginal price; and because there was little differentiation in terms of quality and variety, producers were discouraged from seeking out niche markets by differentiating their product. Additional stabilization schemes were implemented by individual States, such as for fresh milk and eggs, and these led to different incentives in the various States. These were possible only by the
} 
Other policy measures included fertilizer and fuel subsidies, income tax incentives, rural credit measures, involvement in and subsidies to agricultural research and extension, and public investment in land and water development and rural infrastructure - but all those non-product-specific measures combined added the equivalent of no more than 2 percent to Australian farmers’ gross income as of the early 1970s (row 4 of Table 3).

The net effect of both farm and nonfarm policies on agricultural incentives is summarized as the Relative Rate of Assistance (RRA) in Table 3 and Figure 5. In the 1940s the negative effect on incentives from agricultural policies was trivial compared with that from non-agricultural ones, mostly import protection for manufacturers. Together those policies effectively reduced farmers’ gross returns by around 40 percent in the mid-1940s, (Figure 5). Then price stabilization and other agricultural policies gradually provided direct assistance to Australian farmers over the 1950s and 1960s when manufacturing protection remained steady, such that the RRA went from -26 percent during 1946-49 to just under -10 percent by 1965-69. Of that change, about two-thirds is due to changes in non-agricultural policies and only one-third to changes in direct assistance to farmers. Meanwhile, by the late 1960s the home consumption price schemes were imposing tax equivalents of over 100 percent on Australian consumers of butter, cheese, sugar and eggs (Lloyd 1973, Table 10.6).

states agreeing not to trade across State borders, in contravention of Section 92 of the Constitution in which it is stated that there shall be no barriers to inter-State trade. 


\section{The reforms from the early $1970 \mathrm{~s}$}

Disenchantment with Australia's interventionist trade and related economic policies gradually spread in the 1960s, but it was not until the 1970s that tariff reductions began. A 25 percent across-the-board cut in July 1973, proceeded by some minor cuts in 197071, started the tariff reform process. Apart from temporary reversals for cars and textiles, the reform process was accelerated in the 1980s and continued through the 1990s. As a result, over those three decades the average nominal rate of assistance to Australian manufacturing fell from 23 to 3 percent, and the effective rate from 36 to 5 percent. In the 1990s alone, both the mean and the standard deviation of Australia's import tariffs on goods halved. This brought the average tariff for manufactures down to 4.2 percent in 1999. ${ }^{15}$ The only manufacturers with significant tariff protection now are motor vehicles and parts, and textiles, clothing and footwear. Excluding them, the average effective rate of assistance to Australian manufacturing is now less than 3 percent (Productivity Commission 2000a). ${ }^{16}$

\footnotetext{
${ }^{15}$ This average is still higher than for other OECD countries though (World Bank 2006); and Australia’s WTO-bound tariffs average more than twice the applied rates. However, Australia uses non-tariff import barriers less frequently than other OECD countries, apart perhaps from anti-dumping duties (Productivity Commission 2000a, 2000b, 2004).

${ }^{16}$ Tariffs on motor vehicle imports fell from 40 to 15 percent over the 1990s and were cut again to 10 percent in 2005; for clothing the decline over the 1990s was from 55 to 25 percent, and for footwear from 45 to 15 percent, with cuts to 17.5 and 10 percent in 2005, respectively. Further cuts, to as little as 5 percent, are scheduled for 2010 (Productivity Commission 2000a, Table 4.4).
} 
Australia’s agricultural subsidies and regulatory interventions also have been close to eliminated over those 35 years. The average nominal rate of assistance to the farm sector fell from 16 percent in the early 1970s to less than 2 percent this decade, and the standard deviation has fallen from almost 60 percent to less than 1 percent. The process was piecemeal $^{17}$ and gradual, often involving a series of partial steps, but it was persistent. It began in 1972 with manufacturing milk and then two to four years later with cotton and tobacco, while it took another decade before supports for rice and eggs began to be dismantled, and almost a further decade for cuts to grape industry assistance. It was not without at least one significant reversion, with the introduction of the reserve price scheme for wool in 1973 that took until the early 1990s to unravel. ${ }^{18}$

There were just two farm groups still benefiting significantly from government programs in the latter 1990s: tobacco and milk producers, each with an NRA of more than 20 percent in 1997. Deregulation of tobacco marketing arrangements began in 1995 and was completed in 2000, bringing effective assistance to tobacco growing down from

${ }^{17}$ By contrast, the reductions in manufacturing protection were more systematic: the 1973 across-the-board tariff cut, a Tariff Review program begun in 1971 by the Tariff Board and subsequently conducted by its successors (the Industries Assistance/Industry/Productivity Commission), and the pre-announced phased reductions in tariffs on textiles, clothing footwear and motor vehicles and parts from 1988.

${ }^{18}$ The wool price stabilization scheme operated conservatively for 15 years until the government transferred to growers in 1987 the power to set the reserve price. Growers promptly raised that reserve price - which operated on the world market - by 71 percent. Predictably this encouraged growers to expand wool production and international buyers to reduce purchases (since the Australian Wool Corporation would then stockpile wool and thereby save the buyer the cost of storage). The scheme collapsed in 1991 and the AWC had to dispose of its 4.75 million bales, at some expense to the government and at great expense to woolgrowers (Richardson 2001). 
30 to 2 percent over that period. As from 1 July 2000, the remaining impediments to a free domestic market in fluid milk began to be dismantled. An untied, one-off grant (providing a one-off total of around $\$ 1.94$ billion or $\$ 170,000$ per dairy farm) has been paid to dairy farmers by way of compensation, funded by a consumer levy on fresh milk at the retail level over the eight years to 2008. ${ }^{19}$

Thus distortionary government assistance to both manufacturing and agriculture, and hence the overall anti-trade and anti-agricultural biases, have now all but disappeared in Australia - after being in place for more than seven decades. ${ }^{20}$ In the past 35 years it was non-agricultural policy reforms that overwhelmingly contributed to the improvement of farmers' incentives, with the decline in manufacturing protection sufficiently large as to more than offset the decline in direct assistance to farmers from the late 1960s. Farmers have benefited also from the fact that service sectors have not been spared reform. Banking, post and telecommunications, ports, higher education, health, and rail, air and sea transport have been opened up; there has been progressive out-sourcing of many government services; and substantial reforms to competition policy and practice,

${ }^{19}$ Contrary to some pessimistic forecasts at the time, dairy output has continued to increase: production from those leaving the industry (17 percent of producers departed during the first three years) has been more than compensated by output and productivity improvements on remaining farms (Harris 2005a,b). As it happened, the retail price of milk fell after deregulation as the supermarkets were able to exercise buying power with the milk processors which, in turn, were able to exert downward pressure on the farm-gate price which was no longer supported by State governments.

${ }^{20}$ Effective assistance to the mining sector is still slightly negative (Productivity Commission 2004, Chapter 2.5), although that will be less so now that the quantitative restrictions on exports of uranium and its derivatives and the Labor Party's moratorium on new uranium mines have been recently removed. 
including privatization and the corporatization and de-monopolization of numerous government enterprises, are well advanced. ${ }^{21}$ Moreover, following the floating in 1983 of the Australian dollar, foreign investment began to flow more freely. That complemented financial sector reform and contributed to foreign direct investment, equity and foreign currency transactions growing at several times the pace of GDP. Even those labor markets that were previously highly unionized have undergone considerable reform. Households have gained substantially from these widespread reforms, including consumers of food who for the past decade have faced an average tax equivalent of just 2 percent on their food purchases (compared with the OECD average of between 23 and 36 percent over that period, measured at the farm gate level - see OECD 2006).

\section{Prospects for further policy reform}

Notwithstanding the huge amount of reform over the past two decades, a number of important agricultural policy issues remain on the table. The key ones are in the resource and environmental areas. Three are mentioned briefly, by way of illustration.

\footnotetext{
${ }^{21}$ In addition, a comprehensive program of review of government regulations at all levels in Australia has been under way since the mid-1990s, with the aim of reducing/removing regulations that unjustifiably impede economic activities (Productivity Commission 2000b). For an independent assessment of Australia’s domestic microeconomic reforms, see Forsyth (2000). Recent research on barriers to trade in a wide range of services in almost 40 countries found that services markets in Australia, relative to those in the other countries in the study, are now ranked as either very liberal (banking, distribution services, telecoms, engineering professional services) or at worst just moderately restrictive (other professional services, maritime services) - see Productivity Commission (2000c, pp. 50-61).
} 
The first involves food and agricultural import restrictions for the protection of plant, animal and human health. The economic protection from import competition that this provides farmers has not been fully captured in the Productivity Commission's NRA estimates for Australia, especially for horticultural products. Some of that protection may well be warranted on externality grounds, but some (such as a complete ban on imports of certain fruits from all countries) may be excessive from a national welfare viewpoint. The Australian government is slowly examining whether various measures are excessively restrictive, but mainly in response to pressure from other WTO members seeking greater market access. Typically consumer costs are not included in such assessments, nor are all the cheaper ways of reducing any costs associated with the importation of disease (James and Anderson 1998).

Second, Australia so far has not allowed the commercial growing of genetically modified (GM) varieties of farm products, with the sole exceptions of cotton and carnations. While the national Office of the Gene Technology Regulator has approved the commercial growing of GM canola, State governments have placed moratoria on plantings. GM food can be sold only if strict labeling standards are adhered to (FSANZ 2007). These restrictions may or may not be in their economies' and consumers' interests, depending on their impact on market access abroad for ANZ farm products and on human health and the environment at home (Anderson and Jackson 2005), but emotion has played more of a role at the State level in formulating these policies than has sound technical and economic analysis, especially in the growing of GM crops.

Third, environmental and resource policies have become very important in Australian agriculture. Within this area, water policy was already becoming a major 
economic and political issue but was brought to a head in Australia during 2006 following the country's worst drought on record. There has been substantial reform in recent years, but much remains to be done to make the most of this resource, particularly in rural Australia where most of it is used. Proposals for reform and several national enquiries are currently under way (Productivity Commission 2006). More efficient pricing of that resource may lead to substantial reallocations of resources within the agricultural sector, with possible declines in Australian production of cotton, rice, and milk as horticultural industries (and urban areas) bid away water from those farmers. ${ }^{22}$

The remaining big frontier for policy reform that would boost farm incomes in Australia is the dismantling of agricultural subsidies and import protection abroad. A successful conclusion to the Doha Round negotiations in the WTO provides the greatest promise for achieving that outcome: on a per capita basis, Australians - and especially their farmers - would be among the major beneficiaries of a significant agricultural reform outcome from that round. According to global Linkage Model results reported in Anderson, Martin and van der Mensbrugghe (2006, Table 13), removing all merchandise trade barriers and agricultural subsidies globally would raise agricultural value added or net farm incomes in Australia and New Zealand by 26 percent. Even using the GTAP Model, whose supply response elasticities are lower than in Linkage, a similar study by Anderson and Valenzuela (2007, Table 4) reports agricultural value added in Australia and New Zealand would rise by 15 percent, compared with a rise of just 2 percent in value added by their non-agricultural industries.

\footnotetext{
${ }^{22}$ The impact of past under-pricing of water for agriculture on farm returns has not been incorporated in the NRA estimates reported in this paper. Nor does the OECD include it in its PSE calculations.
} 


\section{Comparison with other high-income countries}

How does the overall inter-sector distortions pattern that has evolved for Australia contrast with that for other high-income countries? Comparable new estimates of the relative rate of assistance are now available for all the other major high-income countries from 1955. All have followed a similar path to Australia's in the sense of raising their relative rates of assistance to farmers as their national incomes have risen, but - except for New Zealand - from higher bases and to higher levels than Australia, and more so the weaker their comparative advantage in agriculture. ${ }^{23}$

By contrast, in the United States the RRA averaged around zero between 1955 and 1975, grew to about 4 percent for the next 20 years, and then, since the 1996 Farm Bill, has been about half that but still positive. In Western Europe, the advent of the Common Agricultural Policy, together with similar national support programs in countries prior to their joining the European Union or its predecessors, led to its already high RRA in the latter 1950s (around 20-35 percent) more than doubling in the early 1960s. It remained high through the rest of the $20^{\text {th }}$ century. Because of the use of variable import levies and export restitutions aimed at stabilizing domestic food prices, it fluctuated inversely with international prices (so was lower in the mid-1970s and early

\footnotetext{
${ }^{23}$ New Zealand assistance to non-agricultural producers of tradables (mostly manufacturers) has been even higher there than in Australia since 1955, while assistance to farmers was less except for a period of high farm subsidies from 1975 to 1989. New Zealand's RRA is even lower than Australia's except in the 1980s but, like Australia, New Zealand has virtually completely reformed its sectoral assistance policies affecting tradables, and has had an RRA close to zero since 2000 (Anderson et al. 2007).
} 
and late 1980s, and peaked in the mid-1980s when international food prices reached their lowest in real terms for the century). In Japan, the RRA rose from less than 40 percent prior to the mid-1960s to above 60 percent a decade or so later and to more than 100 percent from the mid-1980s.

Figure 6 summarizes these estimates, showing that the RRA tends to be higher not only with higher per capita income but also with weaker agricultural comparative advantage. While there is a hint of a structural break to the growth of agricultural protection around the time of the Uruguay Round Agreement on Agriculture coming into force in 1995, no other OECD country except New Zealand has made as dramatic a reduction in agricultural assistance - in terms of driving the RRA towards zero - as Australia.

\section{Summary and lessons for other economies}

Even without undertaking historical economy-wide modeling, the results presented above provide some clear answers to the empirical questions posed at the start of this paper.

First, the anti-trade and anti-primary sector biases in Australia’s industry assistance policies were very extensive during the first 25 post-war years. The disincentives this generated for farmers have been progressively falling every half-decade since the 1940s, however, and are now virtually zero (third to last row of Table 3).

Second, the timing of cuts to sector assistance, which gradually reduced those biases over the long term, were such that there were nonetheless numerous reversals in 
the relative rate of assistance for short periods when farm assistance cuts preceded cuts in manufacturing tariffs (bottom line in Figure 5).

Third, the variation of industry assistance rates within the agricultural sector rose during the 1950s to the 1970s, when the standard deviation rose from less than three times to more than six times the weighted mean. That increase in variance probably reduced the second-best welfare contribution of those programs in their offsetting of manufacturing assistance during that period. However, the variation has progressively fallen since the 1970s and is now, like the mean, virtually zero (second-last row of Table 2).

Fourth, the structure of assistance within the agricultural sector has not been as biased against the export industries as is the case in many other countries. True, the average NRA for exportables was below that of import-competing farm industries every half-decade from the Second World War to the early 1980s. However, several major export industries (rice, sugar, cotton, grapes) enjoyed assistance rates above the sector average and, after the early 1980s, exporters enjoyed a higher average rate of assistance than import-competing farm industries (Table 2). Despite this, the reforms were accompanied by a marked increase in the export orientation of numerous farm industries, as reflected in Figure 3.

And fifth, Australia (along with New Zealand) is unusual in having cut its agricultural and trade policies to the point of virtually zero nominal and relative rates of assistance. This case study thus shows that removing even the largest and longest-lasting farm subsidies is politically possible. Even where that was done by providing generous adjustment assistance, such transition support was time-bound. Dairy adjustment 
assistance was able to be financed simply by delaying the rewards to domestic consumers and thereby creating a gap between the producer and consumer price, rather than through outlays from (and hence resistance by) the treasury (see Harris 2005b).

This case study offers hope that good policy analysis and advisory institutions can alter the political economy sufficiently to allow removal of price distortions. More than that, it illustrates the growth dividend that can come from reforming such policies. Having now dismantled virtually all its import protection and agricultural subsidy policies, and having undertaken major domestic macro- and micro-economic reforms over the past two plus decades, the fruits of that undertaking are being reaped. An indicator within the agricultural sector is the acceleration it has given to farm productivity growth (see below).

It needs to be borne in mind that Australian farmers have not been immune from the standard 'small farm problem' that requires them to 'get big or get out' as the economy develops. It is true that their farm sizes were large relative to those in most other market economies in the early post-World War II years, and that the 'wool boom' of the early 1950s provided massive incomes for woolgrowers. Nonetheless, as wages grew elsewhere in the economy, the need to adjust was felt strongly in Australia just as elsewhere; ${ }^{24}$ and it manifested itself in the same way, that is, with farmers funding

\footnotetext{
${ }^{24}$ In the first half of the 1950s, farm incomes averaged more than 20 percent above non-farm self-employed incomes and more than twice those of male wage and salary earners; but in the next dozen years farm incomes fell to 5 percent below non-farm self-employed incomes and to just 30 percent above those of male wage and salary earners (McKay 1967, Table 1). The gap between farm and nonfarm incomes and spending power further increased and grew especially rapidly in the ten years from 1963 (Glau 1971, Figure 1).
} 
agricultural research and adapting and adopting as appropriate the new technologies it generated, and with the number of farms and farmers declining steadily to lower the labor intensity of the sector even as output expanded. ${ }^{25}$

Within that context, the removal of the anti-agricultural policy bias over the past 30 years has boosted, with a not-unexpected delay, the rate of growth of farm productivity substantially. Multifactor farm productivity (MFP) growth increased following the international price hikes in 1973-74, but then plateaued during the next decade until the reforms from the mid-1980s began to have their effect (Figure 7). In the 1983-93 period, farm MFP grew at just 1.4 percent per year, but during 1993-2000 its growth rate was 4.1 percent (Productivity Commission 2005, p.121). Similar results are reported in Parham (2004): less than 1.5 percent during 1974-88, then 2.6 percent in 1988-93 and 4.3 percent in $1993-98 .{ }^{26}$ His estimates show that even that earlier rate of 1.5 percent compares favorably with that for the other sectors of Australia's economy, the

\footnotetext{
${ }^{25}$ For example, Australia's dairy industry saw the following changes over the 25 years to 2004: the number of dairy farmers more than halved (from 22,000 to 10,000), the average herd size increased 2.5 times (from 85 to 210), average annual yield per cow nearly doubled (from 2850 to 4900 litres), and average annual milk production per farm quadrupled, from 0.25 to 1.05 million litres (Productivity Commission 2005, p.131; Harris 2005a). As well, the dairy processing industry has become significantly more productive (Balcombe, Doucouliagos and Fraser 2007). Overall, the number of farmers in Australia has fallen by more than one-third over the past half-century (ABARE 2007).

${ }^{26}$ See also the results since the mid-1970s in Fleming (2007), who shows that MFP growth on Australia's farms enabled producers to cope with the fact that, over the past three decades, the prices they paid for their inputs grew 1.6 percent more per year than the prices they received for their products.
} 
MFP of which was well below 1 percent during 1973-93 (and only 1.8 percent in 199398).

Clearly, farmers are capable not only of surviving without subsidies, but of becoming more productive with their removal - and not with any obviously faster rate of decline in the total number of farmers or farms than occurs with normal economic growth. $^{27}$

Three important aspects of the Australian reform success need to be underlined. One is that it helps if assistance to non-agricultural sectors is cut at the same time. In Australia those other micro- and macro-economic reforms made it easier for farmers to adjust and raise their productivity. This is relevant for those many developing countries that still have industrial protection and behind-the-border restrictions on domestic nonfarm market activities. For other high-income countries, where manufacturing protection rates are already low and the macro economy is well managed, the reduction of high agricultural supports would be more painful unless coupled with adjustment assistance measures.

Second, adjustment to cuts in agricultural assistance is easier the greater the heterogeneity within the agricultural sector. This can take at least two forms.

Heterogeneity in rates of industry assistance within the sector, as captured by the standard deviation of farm industry NRAs shown near the bottom of Table 2, ensures that as high rates of assistance are lowered, resources will find it profitable to move to lightly assisted farm industries. Such transfers are far easier than transferring mobile resources to other

\footnotetext{
${ }^{27}$ Adjustment has been sharper within individual industries of course, especially those that faced dramatic cuts in subsidies such as Australia's dairy industry (see footnote 24).
} 
sectors, and involve much less reduction in the value of sector-specific assets, particularly farm land. For Australia the standard deviation was very high when the cuts in farm assistance began in the early 1970s, whereas for a country such as Norway where the support levels are very similar across farm industries (OECD 2006), there would be much less scope for adjustment within the sector.

The other form of heterogeneity has to do with firm efficiency within each industry. If some farmers are much more efficient than others, then a cut in assistance to that industry typically leads to the less-efficient being bought out by the more-efficient (who often are also the more export-oriented). The productivity effects of that could be substantial (Melitz 2003, Baldwin 2005, Gopinath, Sheldon and Echeverria 2007). In the case of the Australian dairy industry, that force does indeed seem to have been powerful (Harris 2005a), and it may help explain also the rapid rise since the 1980s in the share of production exported by a number of Australia’s agricultural industries, including beef, canola, wine and cotton (see Figure 3 able and Anderson et al. 2007, Appendix Figure 3). The third important aspect of Australia's reform success has to do with the scope and quality of public institutions that can facilitate the development of policy advice, provide policy co-ordination, and administer policy changes. Australia’s legal, accounting and media systems ensure relatively transparent and informed policy debate, and assist in resolving a host of firm-level complications that arise during policy implementation. The lesson for those wishing to emulate the Australian reform experience, especially in a developing country context, is not to underestimate the importance of long-term investments in the development of strong, pro-market, transparent, corruption-free institutions. 


\section{References}

ABARE (2007), Australian Commodities Statistics 2006, accessed at www.abare.gov.au 12 January.

Anderson, K. (1995), “Australia's Changing Trade Pattern and Growth Performance”, Ch. 1 in Australia's Trade Policies, edited by R. Pomfret, London, Melbourne and New York: Oxford University Press.

Anderson, K. (1998), “Are Resource-Abundant Economies Disadvantaged?” Australian Journal of Agricultural and Resource Economics 42(1): 1-23, March.

Anderson, K. (1999), “The WTO Agenda for the New Millennium”, Economic Record 75(228): 77-88, March.

Anderson, K. (2001), “Australia in the International Economy”, Ch. 2 in J. Nieuwenhuysen, P.J. Lloyd and M. Mead (eds.), Reshaping Australia's Economy: Growth with Equity and Sustainability, Cambridge and New York: Cambridge University Press.

Anderson, K. and C. Findlay (1995), "Policies Affecting Primary Sectors”, Ch. 3 in Australia's Trade Policies, edited by R. Pomfret, London, Melbourne and New York: Oxford University Press.

Anderson, K. and R. Garnaut (1987), Australian Protectionism: Extent, Causes and Effects, Boston, London and Sydney: Allen and Unwin.

Anderson, K. and L.A. Jackson (2005), “GM Crop Technology and Trade Restraints: Economic Implications for Australia and New Zealand”, Australian Journal of Agricultural and Resource Economics 49(3): 263-81, September. 
Anderson, K., R. Lattimore, P.J. Lloyd and D. MacLaren (2007), “Distortions to Agriculture in Australia and New Zealand”, Agricultural Distortions Working Paper xx, World Bank, Washington DC, forthcoming August. Downloadable at www.worldbank.org/agdistortions.

Anderson, K., W. Martin and D. van der Mensbrugghe (2006), “Distortions to World Trade: Impacts on Agricultural Markets and Incomes”, Review of Agricultural Economics 28(2): 168-94, Summer.

Anderson, K. and E. Valenzuela (2007), “Do Global Trade Distortions Still Harm Developing Country Farmers?” Review of World Economics/Weltwirtschaftliches Archiv 143(1): 108-39, April.

Arndt, H.W. (1965), “Australia - Developed, Developing or Midway?” The Economic Record 41(95): 418-40, September.

Balcombe, K., H. Doucouliagos and I. Fraser (2007), “Input Use, Output Mix and Industry Deregulation: An Analysis of the Australian Dairy Manufacturing Industry”, Australian Journal of Agricultural and Resource Economics 51(2): 121-35, June.

Baldwin, R.E. (2005), “Heterogeneous Firms and Trade: Testable and Untestable Properties of the Melitz Model”, NBER Working Paper 11471, National Bureau of Economic Research, Cambridge MA.

Butlin, N.G. (1962), Australian Domestic Product, Investment and Foreign Borrowing, 1861-1938/39, Cambridge: Cambridge University Press.

Capling, A. (2001), Australia and the Global Trade System: From Havana to Seattle, Cambridge: Cambridge University Press. 
Card, D. and R.B. Freeman (2002), "What Have Two Decades of British Economic Reform Delivered?” NBER Working Paper 8801, Cambridge MA, February (forthcoming in Seeking a Premier League Economy, edited by R. Blundell, D. Card and R.B. Freeman).

Carmody, A.T. (1952), “The Level of the Australian Tariff: A Study in Method”, Yorkshire Bulletin of Economic and Social Research 4: 51-65, January.

Crawford, J.G. (1939), “Tariff Level Indices”, Economic Record 11: 213-221.

Crawford, J.G. (1968), Australian Trade Policy, 1942-66: A Documentary History, Canberra: ANU Press.

Deardorff, A.V. (1984), “An Exposition and Exploration of Krueger's Trade Model”, Canadian Journal of Economics 5(4): 731-46.

Diewert, W.E. and D. Lawrence (2006), Measuring the Contributions of Productivity and Terms of Trade to Australia's Economic Welfare, Consultancy Report, Canberra: Productivity Commission, March.

Dolman, B., D. Parham and S. Zheng (2007), “Can Australia Match US Productivity Performance?” Staff Working Paper, Canberra: Productivity Commission, March.

Doran, C.R. (1984), “An Historical Perspective on Mining and Economic Change”, pp. 55-84 in The Minerals Sector and the Australian Economy, edited by L.H. Cook and M.G. Porter, Boston, London and Sydney: Allen and Unwin.

Dowrick, S. (2001), “The Australian Productivity Miracle”, Ch. 1 in Restoring Australia's Economy, edited by J. Nieuwenhuysen, P.J. Lloyd and M. Mead, Cambridge and Sydney: Cambridge University Press. 
Edwards, G.W. (2006), “Fifty Years of Agricultural Policy“, presented at the 50th Annual Conference of the Australian of the Australian Agriculture and Resource Economics Society, Sydney, 8-10 February.

Fleming, E. (2007), “Use of the Single Factorial Terms of Trade to Analyse Agricultural Production”, Australian Journal of Agricultural and Resource Economics 51(2): 113-19, June.

Forsyth, P. (2000), “Microeconomic Policies and Structural Change”, in The Australian Economy in the 1990s, edited by D. Gruen and S. Shrestha, Sydney: Reserve Bank of Australia.

FSANZ (2007), “Assessing the Safety of New Foods and Technologies”, Canberra: Food Standards Australia New Zealand. Accessed at www.foodstandards.gov.au/foodmatters/gmfoods/assessingthesafetyof387.cfm.

Gardner, B. (2007), “Distortions to Agricultural Incentives in the United States and Canada”, Agricultural Distortion Working Paper xx, World Bank, Washington DC, forthcoming August.

Glau, T.E. (1971), “The Cost-Price Squeeze on Australia Farm Income”, Australian Journal of Agricultural Economics 15(1): 1-19, April.

Golpinath, M., I. Sheldon and R. Echeverria (2007), “Firm Heterogeneity and International Trade: Implications for Agricultural and Food Industries”, IATRC Trade Policy Issues Paper \#5, March. Accessible at www.iatrcweb.org Groenewegen, P.D. (1983), ”Australian Taxation Policy”, Ch. 4 in Surveys of Australian Economics, Vol. 3, edited by F.H. Gruen, London and Sydney: Allen and Unwin. 
Gruen, F.H. (1968), "Welfare Economics, the Theory of the Second Best, and Australian Agricultural Policy”, mimeo, Monash University, Clayton, Vic.

Harris, D. (2005a), Industry Adjustment to Policy Reform: A Case Study of the Australian Dairy Industry, RIRDC Publication No. 05/110, Canberra: Rural Industries Research and Development Corporation.

Harris, D. (2005b), Rural Industry Adjustment to Trade Related Policy Reform, RIRDC Publication No. 05/173, Canberra: Rural Industries Research and Development Corporation, December.

Harris, S.F. (1964), “Some Measures of Levels of Protection in Australia’s Rural Industries”, Australian Journal of Agricultural Economics, December, 124-44.

Harris, S.F., J.G. Crawford, F.H. Gruen and N. Honan (1974), The Principles of Rural Policy in Australia: A Discussion Paper, Canberra: Australian Government Publishing Service, May.

Hayami, Y. and M. Honma (2007), “Distortions to Agricultural Incentives in Japan, Korea and Taiwan”, Agricultural Distortion Working Paper xx, World Bank, forthcoming August.

Industries Assistance Commission (1976), Assistance to Manufacturing Industries in Australia 1968-69 to 1973-74, Industries Assistance Commission, Canberra.

Industries Assistance Commission (1981), Manufactured Tobacco, Industries Assistance Commission, Canberra.

Industries Assistance Commission (1983a), Assistance to Australian Agriculture, Information Paper, Industries Assistance Commission, Canberra. 
Industries Assistance Commission (1983b), Australian Tobacco Industry, Canberra: Industries Assistance Commission.

Industry Commission (1995), Assistance to Agricultural and Manufacturing Industries, Canberra: Industry Commission.

James, S. and K. Anderson (1998), “On the Need for More Economic Assessment of Quarantine/SPS Policies”, Australian Journal of Agricultural and Resource Economics 42(4): 525-44, December.

Josling, T. (2007), “Distortions to Agricultural Incentives in Western Europe”, Agricultural Distortions Working Paper xx, World Bank, Washington DC, forthcoming August.

Krueger, A.O. (1977), Growth, Distortions and Patterns of Trade Among Many Countries, Princeton, NJ: International Finance Section.

Leamer, E.E. (1987), "Paths of Development in the Three-Factor, n-Good General Equilibrium Model”, Journal of Political Economy 95(5): 961-99.

Lerner, A.P. (1936), “The Symmetry Between Import and Export Taxes”, Economica 3(11): 306-13, August.

Lloyd, P.J. (1973), Non-tariff Distortions of Australian Trade, Canberra: Australian National University Press.

Lloyd, P.J. (1974), “A More General Theory of Price Distortions in an Open Economy”, Journal of International Economics 4(4): 365-86, November.

Lloyd, P.J. (1975), “Tariff Compensation: An Undesirable Policy” Australian Journal of Agricultural Economics 19(3): 146-53, December. 
Lloyd, P.J. (2006), “Fifty Years of Trade Policy in Australia”, Economic Papers 25: 301313, December.

Lloyd, P.J. (2007), “100 Years of Tariff Protection in Australia”, mimeo, University of Melbourne, July.

Maddison, A. (2003), The World Economy: Historical Statistics, Paris: OECD Development Centre.

McKay, D.H. (1967), “The Small-Farm Problem in Australia”, Australian Journal of Agricultural Economics 11(2): 33-52.

Melitz, M. (2003), “The Impact of Trade on Intra-industry Reallocations and Aggregate Industry Productivity”, Econometrica 71(6): 1695-1725.

Mitchell, B.R. (2003a), International Historical Statistics 1750 to 2000: Europe, $5^{\text {th }}$ edition, Cambridge: Cambridge University Press.

Mitchell, B.R. (2003b), International Historical Statistics 1750 to 2000: The Americas, $5^{\text {th }}$ edition, Cambridge: Cambridge University Press.

Mitchell, B.R. (2003c), International Historical Statistics 1750 to 2000: Africa, Asia and Oceania, $5^{\text {th }}$ edition, Cambridge: Cambridge University Press.

Moffatt, G. (1962), “The Australia Import Licencing System: 1952-1960”, Australian Economic Papers 1(1): 119-38, September.

Moffatt, G. (1970), Import Control and Industrialization, Melbourne: Melbourne University Press. 
OECD (2006), Agricultural Policies in OECD Countries: Monitoring and Evaluation 2005, Paris: Organization for Economic Cooperation and Development.

Parham, D. (2004), ”Sources of Australia’s Productivity Revival”, Economic Record 80(249): 239-57, June.

Parham, D., T. Cobbold, R. Dolamore and P. Roberts (1999), Microeconomic Reforms and Australian Productivity: Exploring the Links, Canberra: Productivity Commission.

Pfaffenzeller, S., P. Newbold and A. Rayner (2007), “A Short Note on Updating the Grilli and Yang Commodity Price Index”, World Bank Economic Review 21(1): 151-163.

Productivity Commission (2000a), Review of Australia's General Tariff Arrangements, Canberra: Productivity Commission.

Productivity Commission (2000b), Regulation and its Review 1999-00, Canberra: Productivity Commission.

Productivity Commission (2000c), Trade and Assistance Review 1999-2000, Canberra: Productivity Commission.

Productivity Commission (2003), From Industry Assistance to Productivity: 30 Years of ‘the Commission’, Canberra: Productivity Commission.

Productivity Commission (2004), Trade and Assistance Review 2003-04, Canberra: Productivity Commission.

Productivity Commission (2005), Trends in Australian Agriculture, Research Paper, Canberra: Productivity Commission, June. 
Productivity Commission (2006), Rural Water Use and the Environment: The Role of Market Mechanisms, Canberra: Productivity Commission.

Productivity Commission (2007), Potential Benefits of the National Reform Agenda, Research Paper, Canberra: Productivity Commission, February.

Richardson, B. (2001), “The Politics and Economics of Wool Marketing, 1950-2000”, Australian Journal of Agricultural and Resource Economics 45(1): 95-115.

Sandri, D., E. Valenzuela and K. Anderson (2006), “Compendium of National Economic and Trade Indicators by Region, 1960 to 2004”, Agricultural Distortions Working Paper 01, World Bank, Washington DC, at www.worldbank.org/agdistortions

Sieper, E. (1982), Rationalising Rustic Regulation, Sydney: Centre for Independent Studies.

Snape, R.H. (1984), “Australia’s Relations with GATT”, Economic Record 60(168): 1627, March.

Vernon Committee (1965), Report of the Committee of Enquiry, Melbourne: Wilke and Co.

Vousden, N. (1990), The Economics of Trade Protection, Cambridge and New York: Cambridge University Press.

Warr, P.G. (1978), “The Case Against Tariff Compensation”, Australian Journal of Agricultural Economics 22(2): 85-98, August.

World Bank (2000), Global Commodity Markets: A Comprehensive Review of Price Forecasts, World Bank: Washington DC.

World Bank (2006), World Development Indicators, World Bank: Washington DC. 
Table 1: Sectoral composition of GDP, employment and exports in Australia, 1820 to $2005-06$

(percentage shares, at current prices)

\begin{tabular}{|c|c|c|c|c|c|}
\hline$G D P$ & Agriculture & Mining & Manufacturing & Services & TOTAL \\
\hline $1820-24$ & 53 & $1^{\mathrm{a}}$ & 3 & 43 & 100 \\
\hline $1861-64$ & 23 & 15 & 13 & 49 & 100 \\
\hline $1880-84$ & 24 & 5 & 24 & 47 & 100 \\
\hline $1910-14$ & 23 & 6 & 23 & 48 & 100 \\
\hline $1950-54$ & 22 & 2 & 29 & 47 & 100 \\
\hline $1960-64$ & 16 & 2 & 28 & 54 & 100 \\
\hline $1970-74$ & 9 & 3 & 26 & 62 & 100 \\
\hline $1980-84$ & 5 & 6 & 20 & 69 & 100 \\
\hline $1990-94$ & 3 & 5 & 15 & 78 & 100 \\
\hline 2005-06 & 3 & 4 & 11 & 82 & 100 \\
\hline Employment & Agriculture & Mining & Manufacturing & Services & TOTAL \\
\hline $1962-63$ & 10 & 1 & 26 & 63 & 100 \\
\hline $1972-73$ & 7 & 1 & 24 & 68 & 100 \\
\hline $1982-83$ & 6 & 1 & 19 & 74 & 100 \\
\hline 1993-94 & 5 & 1 & 14 & 80 & 100 \\
\hline 2005-06 & 3 & 1 & 10 & 85 & 100 \\
\hline Exports & Agriculture & Mining & $\begin{array}{c}\text { Other } \\
\text { merchandise }\end{array}$ & Services & TOTAL \\
\hline $1950-51$ & 86 & 6 & 3 & 5 & 100 \\
\hline 1962-63 & 66 & 8 & 13 & 13 & 100 \\
\hline $1972-73$ & 44 & 28 & 12 & 16 & 100 \\
\hline $1982-83$ & 39 & 34 & 11 & 16 & 100 \\
\hline $1993-94$ & 26 & 41 & 14 & 19 & 100 \\
\hline 2005-06 & 21 & 35 & 22 & 22 & 100 \\
\hline
\end{tabular}

${ }^{a}$ Assumes mining is one-quarter of the total of mining and manufacturing in 1820-24

Sources: ABARE (2007) and, for GDP prior to the 1960s, Mitchell (2003c) and Butlin (1962). 
Table 2: Nominal rates of assistance to selected agricultural industries in Australia, 1946-47 to 2004-05

(percent, for fiscal years starting 1 July)

\begin{tabular}{|c|c|c|c|c|c|c|c|c|c|c|c|c|}
\hline & 1946-49 & $1950-54$ & 1955-59 & 1960-64 & 1965-69 & $1970-74$ & 1975-79 & $1980-84$ & 1985-89 & $1990-94$ & 1995-99 & 2000-04 \\
\hline Exportables $^{\text {a }}$ & -7.5 & 0.9 & 6.4 & 7.0 & 10.0 & 7.6 & 3.6 & 4.6 & 5.6 & 4.8 & 3.0 & 0.0 \\
\hline Rice & -3.2 & -1.1 & 11.4 & 15.0 & 14.8 & 22.0 & 20.4 & 15.2 & 10.6 & 2.5 & 2.3 & 1.7 \\
\hline Wheat & -24.2 & -8.4 & 1.9 & 6.1 & 10.1 & 7.2 & -0.4 & 2.6 & 3.8 & 2.1 & 1.1 & 0.0 \\
\hline Barley & -14.1 & -5.8 & 4.1 & 3.1 & 4.4 & 0.0 & 0.0 & 0.0 & 0.0 & 0.0 & 0.0 & 0.0 \\
\hline Oats & 0.0 & 0.0 & 0.0 & 0.0 & 0.0 & 0.0 & 0.0 & 0.0 & 0.0 & 0.0 & 0.0 & 0.0 \\
\hline Grapes, total & 10.5 & 4.5 & 5.6 & 9.7 & 18.7 & 37.4 & 19.0 & 20.9 & 18.3 & 13.3 & 4.9 & 0.0 \\
\hline Sugar & -8.2 & 0.7 & 12.8 & 15.9 & 32.8 & 7.6 & -6.2 & 4.6 & 12.4 & 5.8 & 1.7 & 0.0 \\
\hline Cotton & 0.8 & 2.0 & 26.7 & 52.1 & 73.9 & 53.4 & 17.6 & 4.4 & 2.0 & 0.0 & 0.0 & 0.0 \\
\hline Wool & 0.0 & 0.0 & 0.0 & 0.0 & 0.0 & 6.0 & 1.4 & 1.0 & 1.0 & 5.4 & 0.7 & 0.0 \\
\hline Beef and veal & 0.0 & 0.0 & 0.0 & 0.0 & 0.0 & 1.4 & 1.8 & 1.4 & 1.2 & 0.3 & 0.0 & 0.0 \\
\hline Mutton and lamb & 0.0 & 0.0 & 0.0 & 0.0 & 0.4 & 1.6 & 1.8 & 1.4 & 1.8 & 0.9 & 0.0 & 0.0 \\
\hline Pigmeat & 0.0 & 0.0 & 0.0 & 0.0 & 0.0 & 0.0 & 0.0 & 0.0 & 0.0 & 0.0 & 0.0 & 0.0 \\
\hline Milk & 2.1 & 18.7 & 46.9 & 43.1 & 74.5 & 32.8 & 35.8 & 32.2 & 39.6 & 23.8 & 19.3 & 0.0 \\
\hline Import competing a & 0.0 & 10.1 & 13.4 & 12.5 & 13.1 & 18.3 & 11.6 & 8.0 & 3.7 & 1.8 & 0.4 & 0.1 \\
\hline Maize & 0.0 & 0.0 & 0.0 & 0.0 & 0.0 & 0.0 & 0.0 & 0.0 & 0.0 & 0.0 & 0.0 & 0.0 \\
\hline Sorghum & 0.0 & 0.0 & 0.0 & 0.0 & 0.0 & 0.0 & 0.0 & 1.6 & 2.0 & 0.0 & 0.0 & 0.0 \\
\hline Oilseeds & 0.0 & 0.0 & 0.0 & 0.0 & 0.0 & 0.0 & 0.0 & 0.0 & 0.0 & 0.0 & 0.0 & 0.0 \\
\hline Tobacco & 0.0 & 34.2 & 51.0 & 46.9 & 51.3 & 250.0 & 122.2 & 56.4 & 37.6 & 48.5 & 19.8 & 0.0 \\
\hline Chicken meat & 0.0 & 0.0 & 0.0 & 0.0 & 0.0 & 0.0 & 0.0 & 0.0 & 0.0 & 0.0 & 0.0 & 0.0 \\
\hline Nontradables ${ }^{\text {a }}$ & -1.2 & 12.6 & 31.4 & 41.6 & 78.1 & 25.3 & 19.5 & 24.2 & 12.2 & 1.8 & 0.2 & 0.0 \\
\hline Eggs & -1.7 & 14.7 & 43.7 & 61.8 & 141.2 & 35.0 & 26.0 & 35.8 & 18.4 & 3.4 & 0.4 & 0.0 \\
\hline Potatoes & 0.0 & 8.0 & 8.0 & 8.0 & 8.0 & 7.2 & 7.2 & 8.0 & 3.2 & 0.0 & 0.0 & 0.0 \\
\hline Total of covered products ${ }^{\text {a }}$ & -7.0 & 1.8 & 7.8 & 8.5 & 12.3 & 8.8 & 4.6 & 5.4 & 5.7 & 4.4 & 2.6 & 0.0 \\
\hline Std. dev. of covered products ${ }^{b}$ & 9.7 & 11.6 & 17.0 & 20.8 & 35.3 & 53.3 & 27.7 & 17.4 & 12.5 & 11.1 & 5.8 & 0.4 \\
\hline \% coverage (at undist. prices) & 91 & 84 & 81 & 86 & 87 & 85 & 85 & 86 & 76 & 83 & 80 & 78 \\
\hline
\end{tabular}

${ }^{a}$ Weighted averages, with weights based on the unassisted value of production (actual back to 1966, and the average for 1966-69 for earlier years). The standard deviation shown is the simple 5-year average of the annual standard deviation around the weighted mean.

Source: Anderson, Lattimore, Lloyd and MacLaren (2007) 
Table 3: Nominal rates of assistance to agricultural relative to non-agricultural industries in Australia, 1946-47 to 2004-05

\begin{tabular}{|c|c|c|c|c|c|c|c|c|c|c|c|c|}
\hline (a) Australia & 1946-49 & 1950-54 & 1955-59 & 1960-64 & $1965-69$ & $1970-74$ & 1975-79 & $1980-84$ & 1985-89 & 1990-94 & 1995-99 & 2000-04 \\
\hline Covered products & -7.0 & 1.8 & 7.8 & 8.5 & 12.3 & 8.8 & 4.6 & 5.4 & 5.7 & 4.4 & 2.6 & 0.0 \\
\hline Non-covered & 0.0 & 0.0 & 0.0 & 0.0 & 0.0 & 0.0 & 0.0 & 0.0 & 0.0 & 0.0 & 0.0 & 0.0 \\
\hline All agric. products ${ }^{\mathrm{a}}$ & -6.4 & 1.5 & 6.3 & 7.4 & 10.7 & 7.6 & 3.9 & 4.6 & 4.4 & 3.7 & 2.1 & 0.0 \\
\hline Non-product specific & 0.6 & 1.2 & 1.8 & 2.1 & 2.0 & 1.9 & 1.4 & 1.1 & 0.9 & 0.7 & 0.8 & 0.5 \\
\hline $\begin{array}{l}\text { Total Agricultural } \\
\text { NRA (incl. NPS) }\end{array}$ & -5.7 & 2.7 & 8.1 & 9.5 & 12.7 & 9.4 & 5.3 & 5.8 & 5.3 & 4.4 & 2.9 & 0.5 \\
\hline \multicolumn{13}{|c|}{ Assistance to just tradables: } \\
\hline All agric. tradables & -5.9 & 2.3 & 7.3 & 8.4 & 10.9 & 8.9 & 4.9 & 5.2 & 5.1 & 4.5 & 3.0 & 0.5 \\
\hline All non-ag trad. & 28.0 & 23.5 & 19.6 & 20.7 & 20.7 & 16.8 & 12.0 & 11.1 & 8.2 & 5.3 & 2.6 & 2.0 \\
\hline $\begin{array}{l}\text { Relative Rate of } \\
\text { Assistance, RRA }\end{array}$ & -26.3 & -17.1 & -10.3 & -10.2 & -8.2 & -6.8 & -6.4 & -5.3 & -2.9 & -0.7 & 0.4 & -1.5 \\
\hline
\end{tabular}

\footnotetext{
${ }^{a}$ Before including Non-Product Specific (NPS) assistance.

${ }^{\mathrm{b}}$ Total of assistance to primary factors and intermediate inputs divided to total value of primary agriculture production at undistorted prices (\%).

${ }^{\mathrm{c}}$ The Relative Rate of Assistance, RRA = 100[(1+NRAag/100)/(1+NRAnonag/100) - 1], where NRAag ${ }^{\mathrm{t}}$ and NRAnonag $^{\mathrm{t}}$ are the $^{\mathrm{t}}$ average percentage NRAs for the tradables parts of the agricultural and non-agricultural sectors, respectively

Source: Anderson, Lattimore, Lloyd and MacLaren (2007)
} 
Figure 1: Real GDP per capita in Australia and other high-income countries relative to the United States, 1945 to 2004 $($ United States $=1.0)$

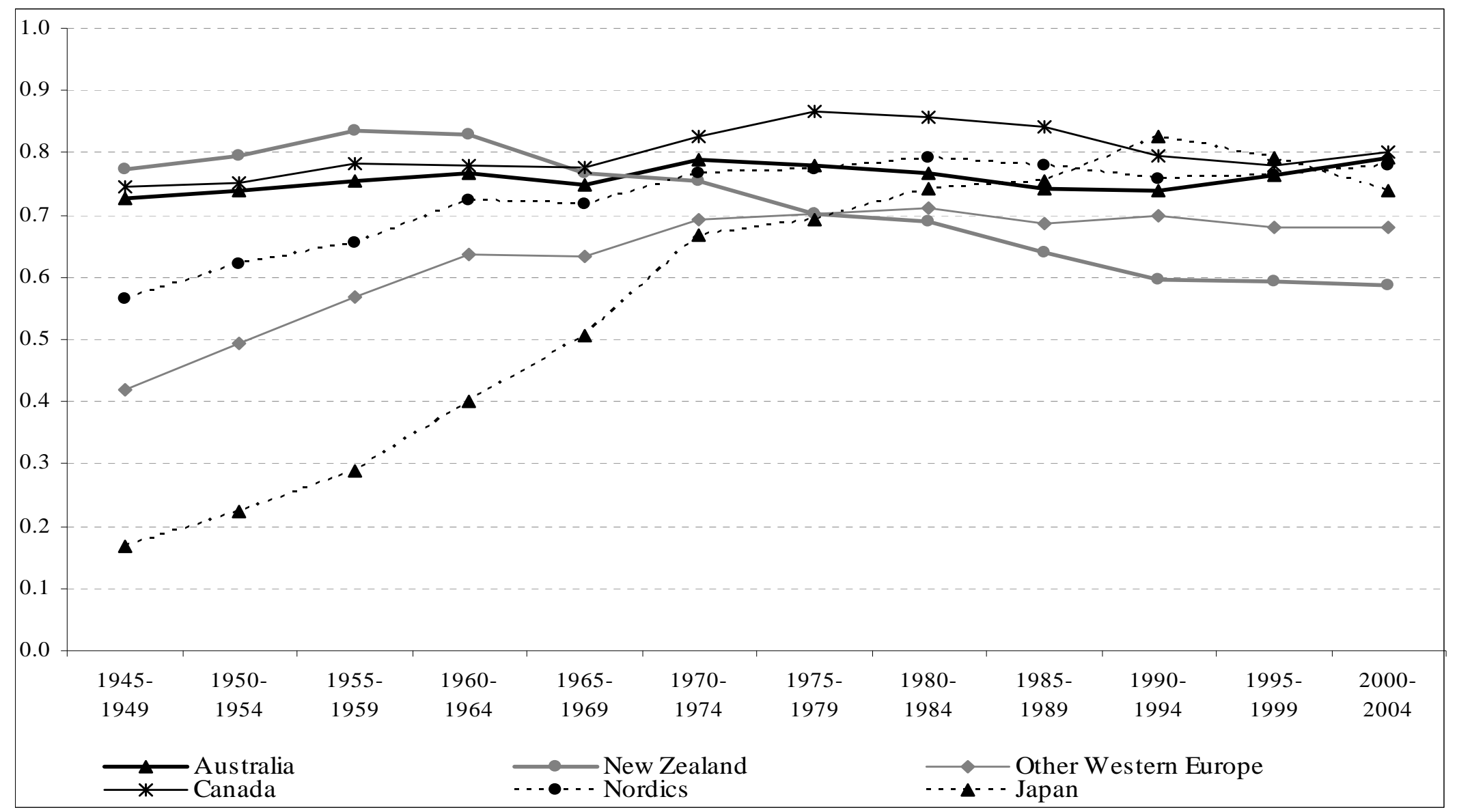

Source: Based on 1990 International Geary-Khamis dollars from Maddison (2003), shown relative to the United States which is set as the numeraire at 1.00. 'Nordics' includes Denmark, Finland, Norway and Sweden; 'Other Western Europe' includes all with data from 1870, namely Belgium, France, Germany, Italy, Netherlands, Portugal, Spain, Switzerland, and the United Kingdom. 
Figure 2: Merchandise exports plus imports as a share of GDP, Australia and other highincome countries, ${ }^{\mathrm{a}} 1945$ to 2005

(percent, five-year averages)

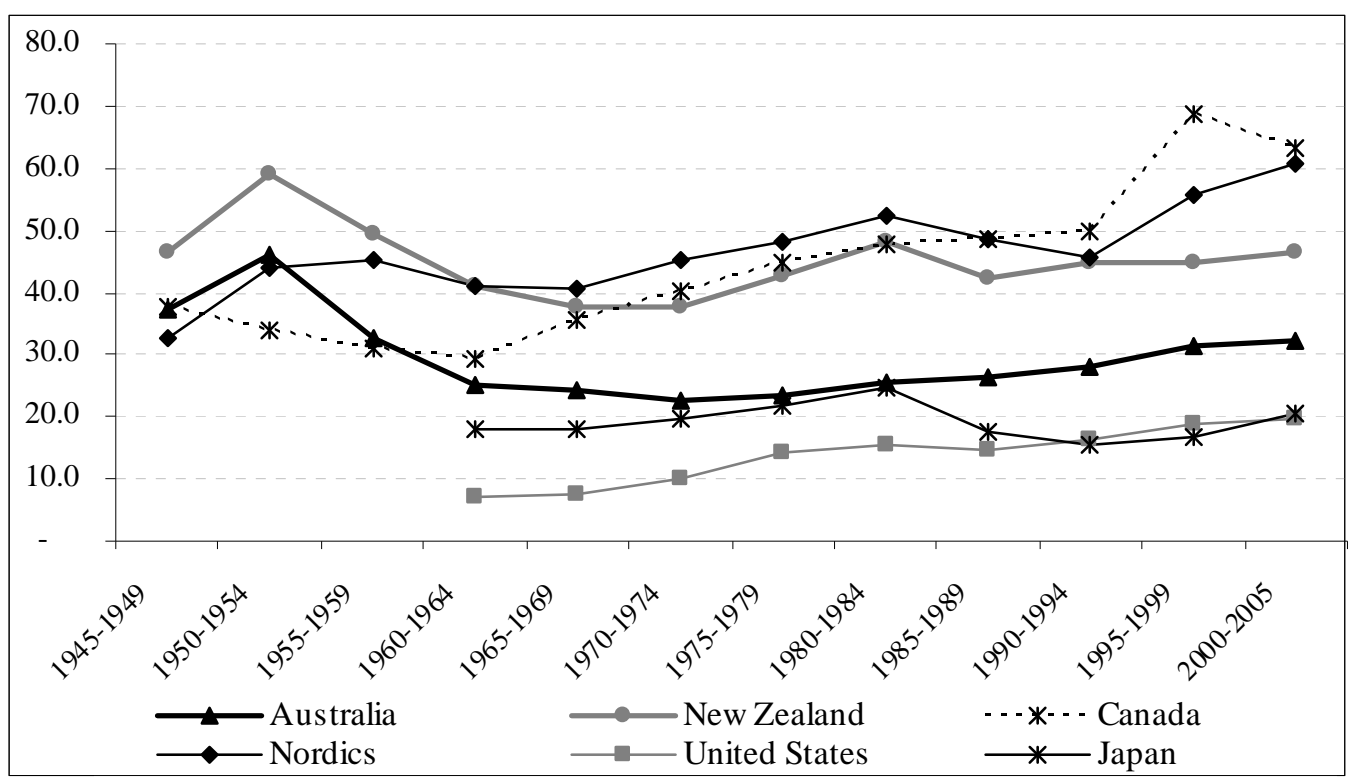

a 'Nordics' refers to the weighted average for Denmark, Finland, Norway and Sweden, using mid-period imports as the weights for each 5-year period.

Source: Mitchell (2003a,b,c), World Bank (2006) 
Figure 3: Commodity composition of agricultural and food exports, Australia, 1970-71 to 2005-06

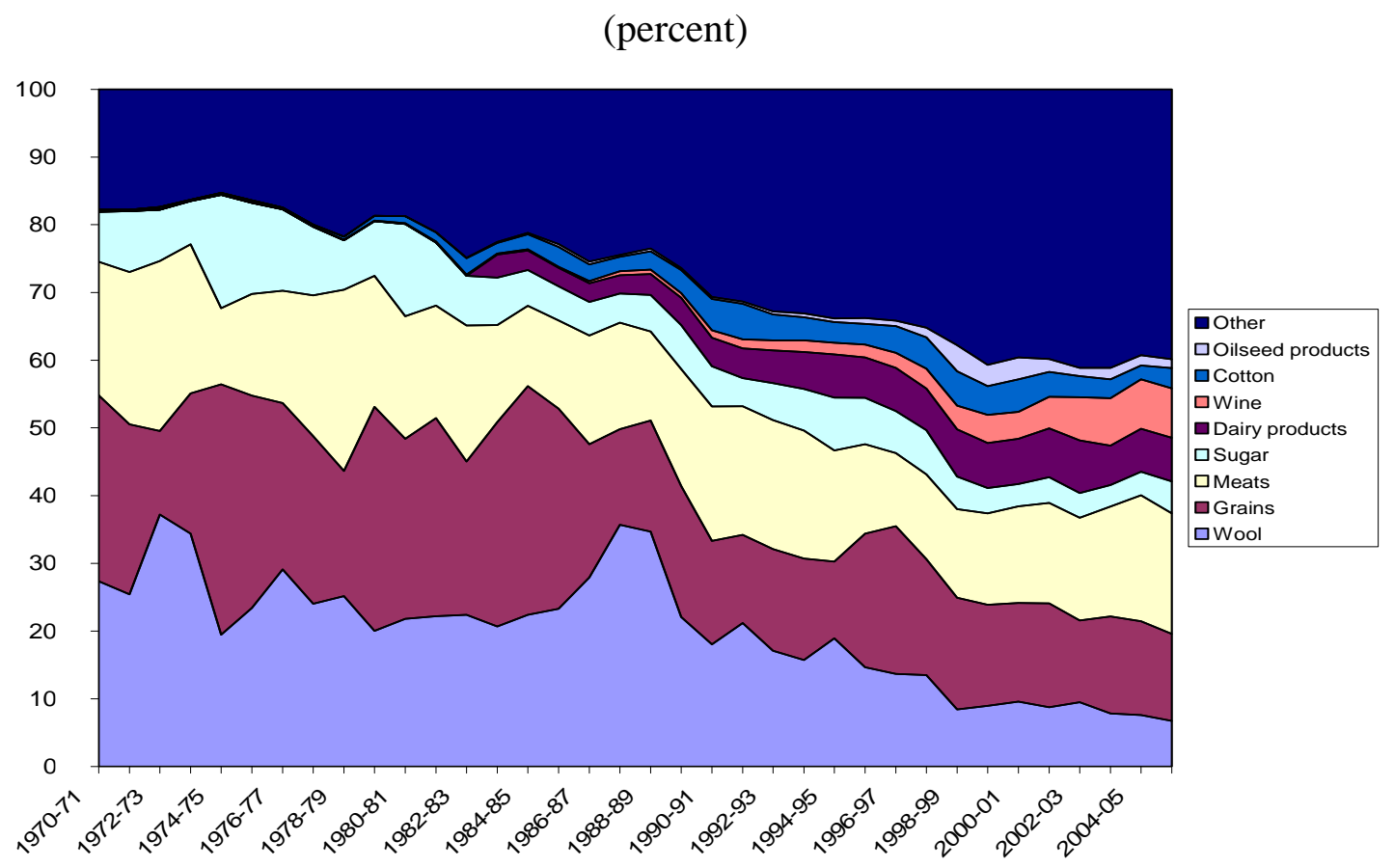

Source: Compiled from data from ABARE (2007 and earlier years) 
Figure 4: Nominal rates of assistance to exportable, import-competing and all ${ }^{\mathrm{a}}$ agricultural industries, Australia, 1946-47 to 2004-05

(percent)

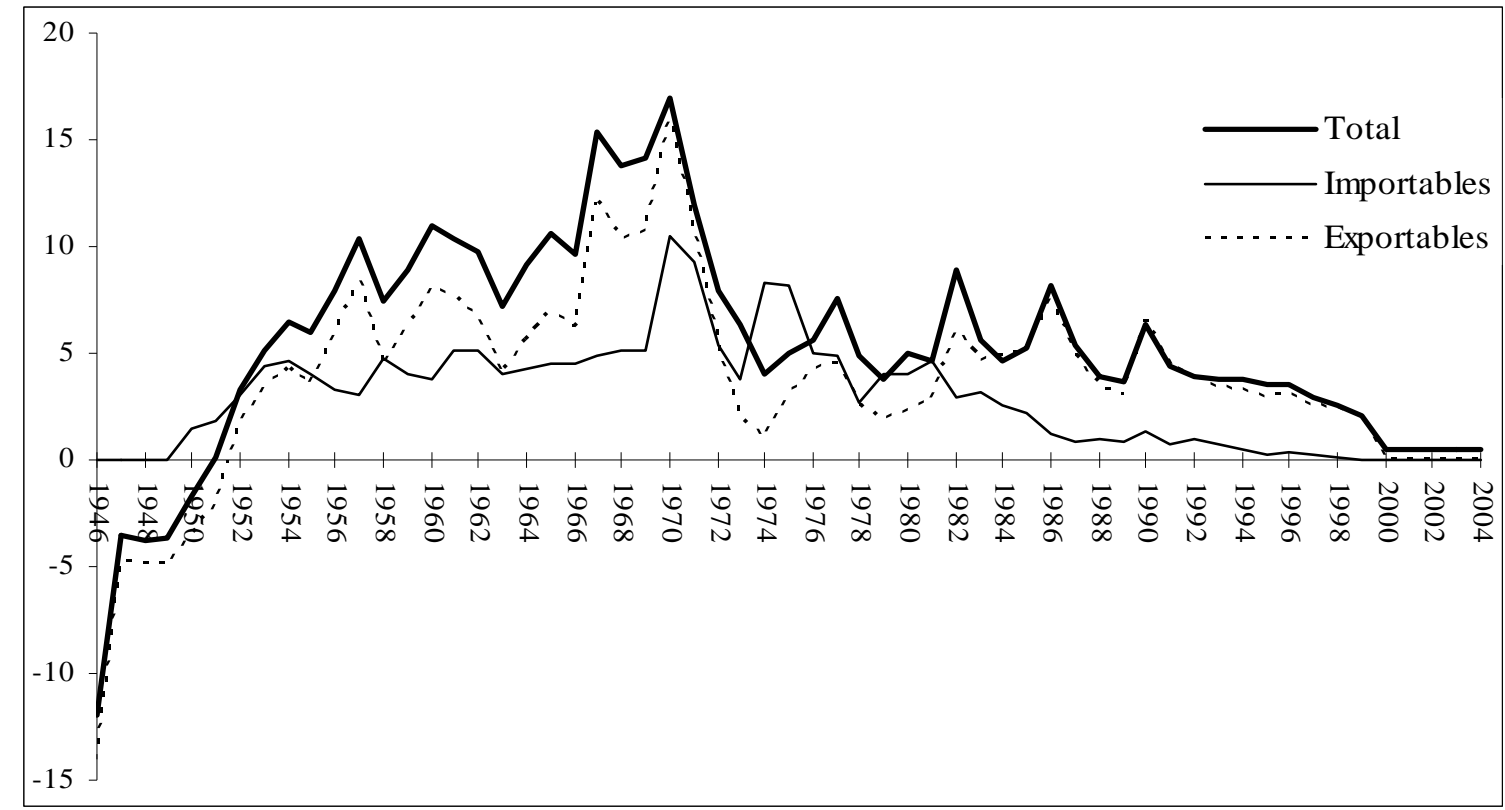

${ }^{\mathrm{a}}$ The total NRA can be above both the exportable and importable averages because assistance to nontradables (eg, eggs) and non-product-specific assistance is also included.

Source: Anderson, Lattimore, Lloyd and MacLaren (2007) 
Figure 5: Nominal rates of assistance to manufacturing, all non-agricultural tradables, all agricultural tradable industries, and relative rate of assistance, ${ }^{\mathrm{a}}$ Australia, 1946-47 to 2004-05

(percent)

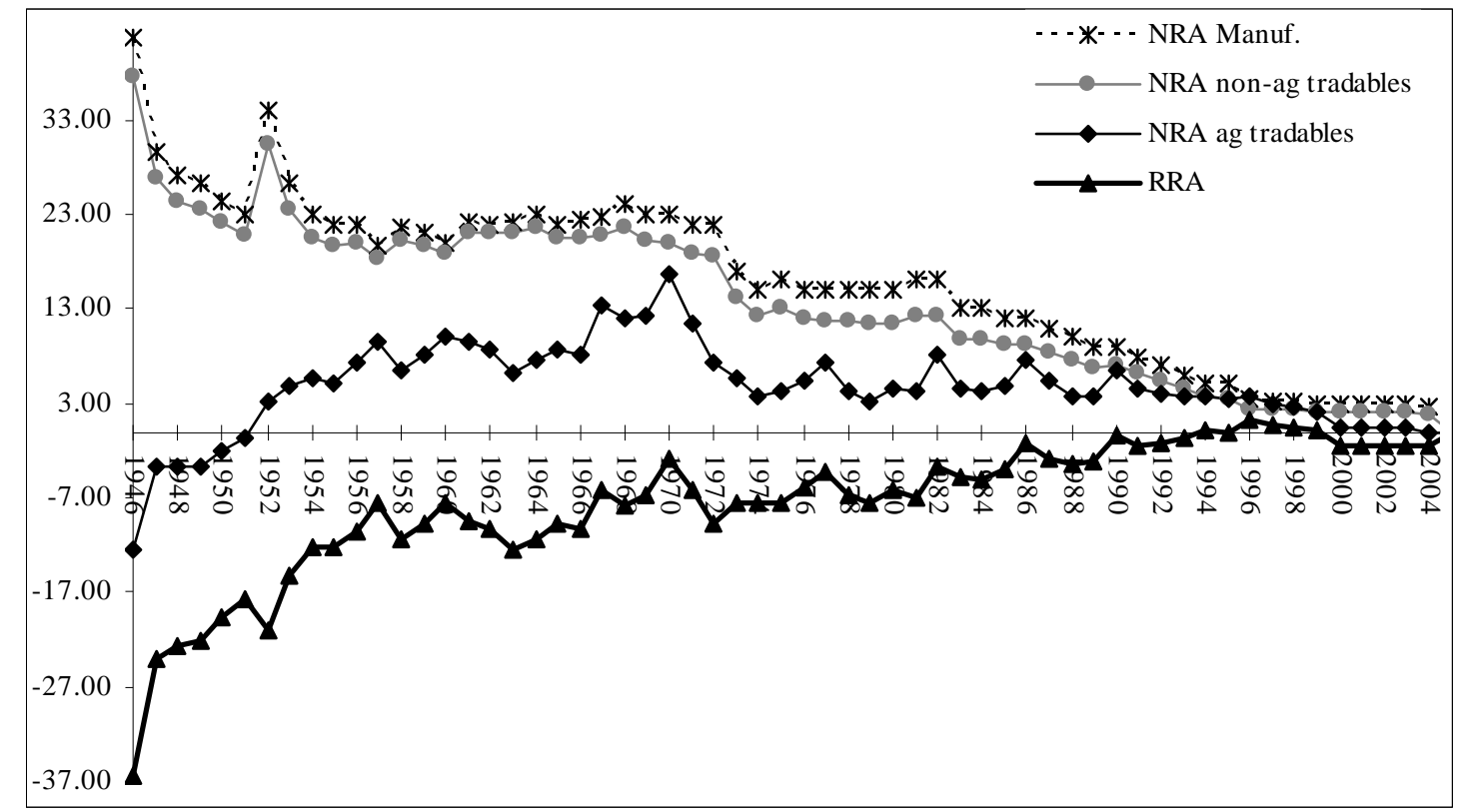

${ }^{\mathrm{a}}$ The RRA is defined as $100 *\left[\left(100+\mathrm{NRAag}^{\mathrm{t}}\right) /\left(100+\mathrm{NRAnonag}^{\mathrm{t}}\right)-1\right]$

Source: Anderson, Lattimore, Lloyd and MacLaren (2007) 
Figure 6: Relative rates of assistance to agriculture, ${ }^{\text {a }}$ Australia and other high-income countries, 1956 to 2004

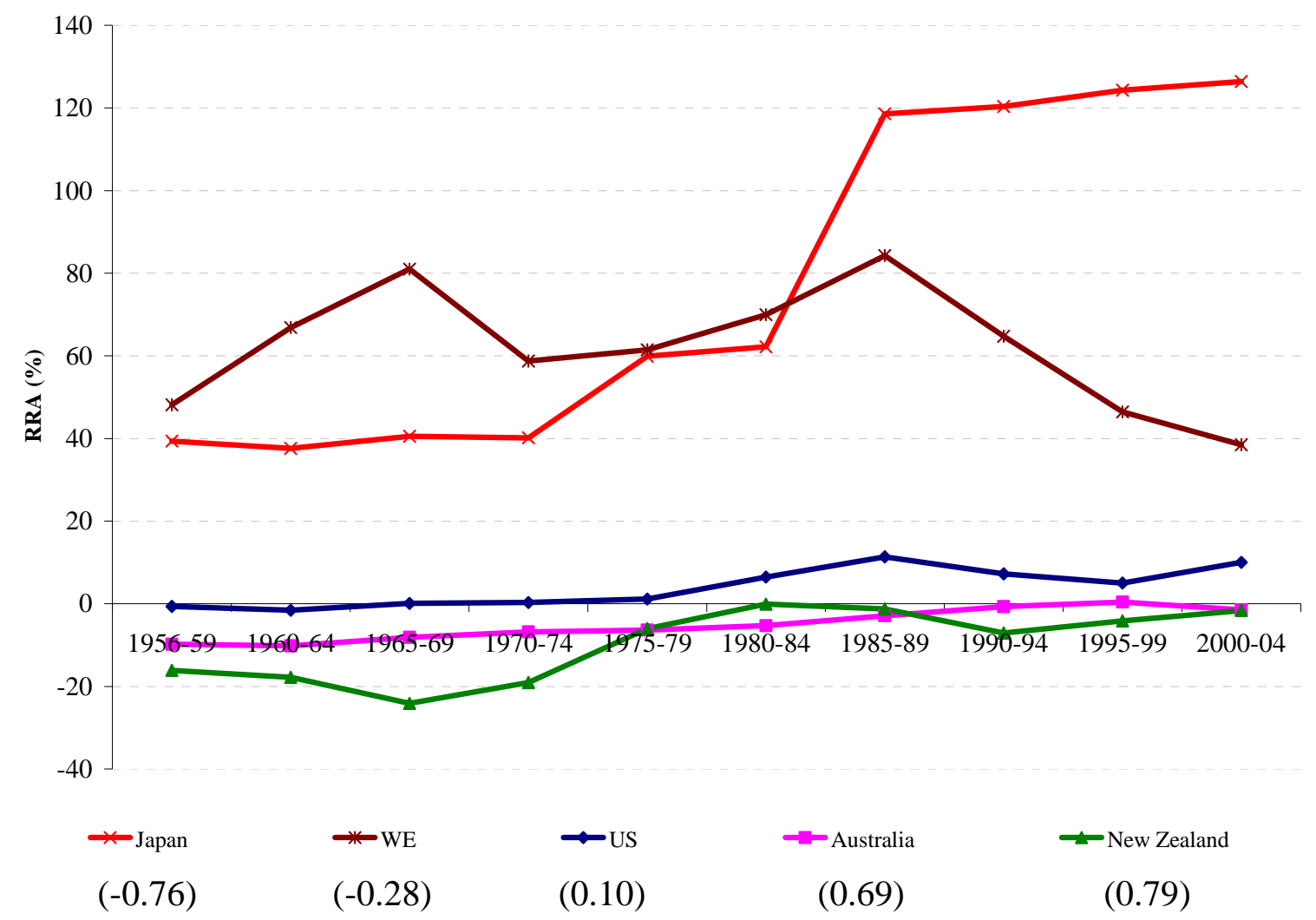

${ }^{a}$ The RRA is defined as $100 *\left[\left(100+N R A a g^{t}\right) /\left(100+N R A n o n a g{ }^{t}\right)-1\right]$. The numbers in brackets are indexes of agricultural comparative advantage, defined as net exports as a ratio of the sum of exports and imports of agricultural and processed food products (hence bound between -1 and +1), averaged over the twenty years from 1960, from Sandri, Valenzuela and Anderson (2006).

Source: Anderson, Lattimore, Lloyd and MacLaren (2007), Gardner (2007), Hayami and Honma (2007), Josling (2007) 
Figure 7: Real multifactor farm productivity growth, Australia, 1974-75 to 2003-04

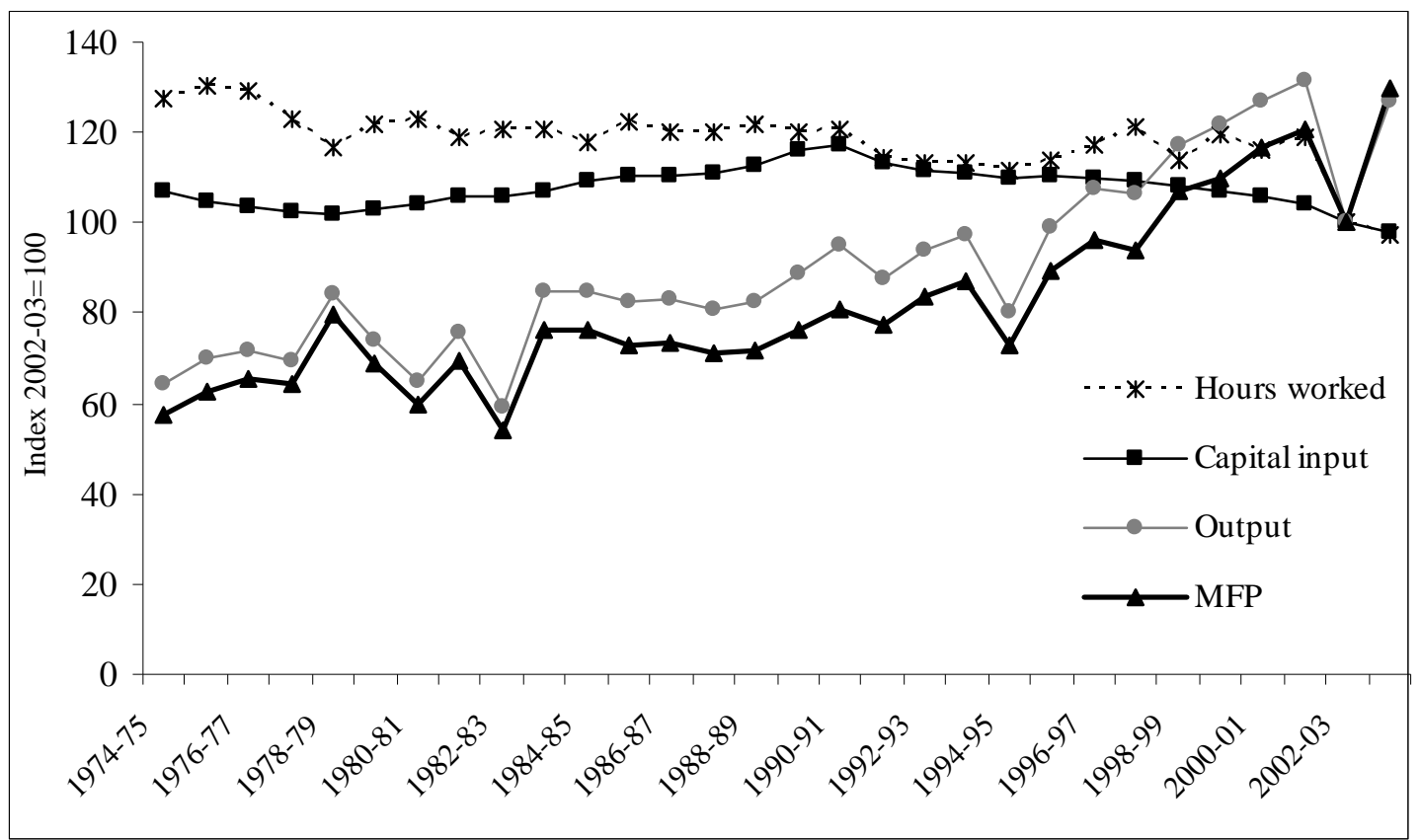

Sources: Productivity Commission (2005, p.121) 
Appendix Table 1: Customs revenue as a share of imports and nominal rate of assistance for manufacturing, Australia, $1945-46$ to $2004-05^{\mathrm{a}}$

(percent)

\begin{tabular}{|c|c|c|c|c|c|}
\hline & $\begin{array}{l}\text { Net }^{\mathrm{b}} \text { customs } \\
\text { plus primage, } \\
\text { all imports }\end{array}$ & $\begin{array}{l}\text { Net }^{\mathrm{b}} \text { customs } \\
\text { plus primage, } \\
\text { dutiable } \\
\text { imports }\end{array}$ & $\begin{array}{l}\text { Nominal rate of } \\
\text { assistance, } \\
\text { manufacturing }\end{array}$ & $\begin{array}{l}\text { Assumed share } \\
\text { of manufacturing } \\
\text { in total value of } \\
\text { non-ag tradables }\end{array}$ & $\begin{array}{c}\text { Average NRA } \\
\text { for non-ag } \\
\text { tradables }\end{array}$ \\
\hline $1945-46$ & 18.2 & 47.1 & na & 90.0 & 42.4 \\
\hline $1946-47$ & 24.8 & 46.9 & na & 90.0 & 42.2 \\
\hline $1947-48$ & 17.0 & 29.7 & na & 90.0 & 26.7 \\
\hline $1948-49$ & 15.3 & 27.0 & na & 90.0 & 24.3 \\
\hline $1949-50$ & 14.5 & 26.2 & na & 90.0 & 23.6 \\
\hline 1950-51 & 12.4 & 24.5 & na & 90.0 & 22.1 \\
\hline 1951-52 & 10.9 & 23.0 & na & 90.0 & 20.7 \\
\hline $1952-53$ & 13.9 & 33.9 & na & 90.0 & 30.5 \\
\hline $1953-54$ & 14.0 & 26.3 & na & 90.0 & 23.7 \\
\hline 1954-55 & 12.0 & 22.9 & na & 90.0 & 20.6 \\
\hline $1955-56$ & 10.7 & 22.0 & na & 90.0 & 19.8 \\
\hline $1956-57$ & 9.6 & 21.9 & na & 91.0 & 19.9 \\
\hline $1957-58$ & 9.1 & 19.8 & na & 92.0 & 18.2 \\
\hline 1958-59 & 9.0 & 21.7 & na & 93.0 & 20.2 \\
\hline 1959-60 & 9.1 & 21.2 & na & 93.0 & 19.7 \\
\hline 1960-61 & 9.4 & 20.0 & na & 94.0 & 18.8 \\
\hline 1961-62 & 9.6 & 22.1 & na & 95.0 & 21.0 \\
\hline 1962-63 & 9.7 & 22.0 & na & 96.0 & 21.1 \\
\hline 1963-64 & 9.8 & 22.3 & na & 95.0 & 21.2 \\
\hline 1964-65 & 9.8 & 22.9 & na & 94.0 & 21.5 \\
\hline 1965-66 & 9.3 & 22.0 & na & 93.0 & 20.5 \\
\hline 1966-67 & 9.1 & 22.4 & na & 92.0 & 20.6 \\
\hline 1967-68 & 9.6 & 22.8 & na & 91.0 & 20.7 \\
\hline 1968-69 & 10.1 & 23.0 & 24.0 & 90.0 & 21.6 \\
\hline 1969-70 & 10.7 & 23.3 & 23.0 & 88.0 & 20.2 \\
\hline 1970-71 & 12.4 & 25.5 & 23.0 & 87.0 & 20.0 \\
\hline 1971-72 & 12.9 & 26.6 & 22.0 & 86.0 & 18.9 \\
\hline 1972-73 & 13.2 & 30.1 & 22.0 & 85.0 & 18.7 \\
\hline 1973-74 & 10.4 & 26.8 & 17.0 & 84.0 & 14.3 \\
\hline 1974-75 & 10.8 & 28.6 & 15.0 & 82.0 & 12.3 \\
\hline 1975-76 & 11.7 & 29.7 & 16.0 & 81.0 & 13.0 \\
\hline 1976-77 & 11.5 & 29.4 & 15.0 & 80.0 & 12.0 \\
\hline $1977-78$ & 10.4 & 29.0 & 15.0 & 79.0 & 11.9 \\
\hline 1978-79 & 10.2 & 31.3 & 15.0 & 78.0 & 11.7 \\
\hline 1979-80 & 9.9 & 28.8 & 15.0 & 77.0 & 11.6 \\
\hline 1980-81 & 9.7 & 28.4 & 15.0 & 76.0 & 11.4 \\
\hline 1981-82 & 9.2 & 27.7 & 16.0 & 76.0 & 12.2 \\
\hline 1982-83 & 9.5 & 28.1 & 16.0 & 76.0 & 12.2 \\
\hline 1983-84 & 9.9 & 27.0 & 13.0 & 76.0 & 9.9 \\
\hline 1984-85 & 10.0 & 27.0 & 13.0 & 76.0 & 9.9 \\
\hline $1985-86$ & 9.6 & 26.3 & 12.0 & 76.0 & 9.1 \\
\hline $1986-87$ & 8.7 & 24.8 & 12.0 & 76.0 & 9.1 \\
\hline 1987-88 & 8.9 & 24.3 & 11.0 & 76.0 & 8.4 \\
\hline
\end{tabular}




\begin{tabular}{lrrrrr}
\hline & $\begin{array}{c}\text { Net }{ }^{\mathrm{b}} \text { customs } \\
\text { plus primage, } \\
\text { all imports }\end{array}$ & $\begin{array}{c}\text { Net }{ }^{\mathrm{b}} \text { customs } \\
\text { plus primage, } \\
\text { dutiable } \\
\text { imports }\end{array}$ & $\begin{array}{c}\text { Nominal rate of } \\
\text { assistance, } \\
\text { manufacturing }\end{array}$ & $\begin{array}{c}\text { Assumed share } \\
\text { of manufacturing } \\
\text { in total value of } \\
\text { non-ag tradables }\end{array}$ & $\begin{array}{c}\text { Average NRA } \\
\text { for non-ag } \\
\text { tradables }\end{array}$ \\
\hline $1988-89$ & 8.3 & 23.5 & 10.0 & 76.0 & 7.6 \\
$1989-90$ & 8.0 & 22.9 & 9.0 & 76.0 & 6.8 \\
$1990-91$ & 7.3 & 21.3 & 9.0 & 77.0 & 6.9 \\
$1991-92$ & 6.9 & 20.4 & 8.0 & 77.0 & 6.2 \\
$1992-93$ & 6.0 & 18.9 & 7.0 & 76.0 & 5.3 \\
$1993-94$ & 5.4 & 17.1 & 6.0 & 74.0 & 4.4 \\
$1994-95$ & 4.9 & 16.1 & 5.0 & 73.0 & 3.7 \\
$1995-96$ & 4.3 & 14.7 & 5.0 & 72.0 & 3.6 \\
$1996-97$ & 4.4 & 12.2 & 3.5 & 72.0 & 2.5 \\
$1997-98$ & 4.4 & 11.3 & 3.3 & 71.0 & 2.3 \\
$1998-99$ & 4.1 & 10.9 & 3.2 & 71.0 & 2.2 \\
$1999-00$ & 3.7 & 10.6 & 3.0 & 71.0 & 2.1 \\
$2000-01$ & 4.0 & 11.2 & 2.8 & 71.0 & 2.0 \\
$2001-02$ & 4.0 & 10.4 & 2.8 & 71.0 & 2.0 \\
$2002-03$ & 3.9 & 10.0 & 2.8 & 71.0 & 2.0 \\
$2003-04$ & 3.9 & 10.0 & 2.8 & 72.0 & 2.0 \\
$2004-05$ & 3.5 & 9.5 & 2.6 & 72.0 & 1.9
\end{tabular}

${ }^{a}$ The five-year averages shown for the period before 1945-46 refer to financial years beginning 1 July

${ }^{b}$ Net of refunds and drawbacks of customs and primage duties

${ }^{\mathrm{c}}$ The NRA for non-agricultural tradables other than import-competing manufacturing is assumed to be zero, so the final column is column 2 up to 1967-68 (column 3 thereafter) times column 4 divided by 100 Sources: Lloyd (2006, 2007) based on data from Australian Bureau of Statistics files and, for the final column from 1968-69, Productivity Commission (2003) and Industry Commission (1995) 